\title{
Hadis Istılahlarından Mühmel ve Sahîh-i Buhârî Ricâlinden Süfyân'ın Tayini Meselesi
}

\author{
Dr. Serkan ÇELIKKAN ${ }^{*}$
}

Atıf / @- Çelikan, S. (2018). Hadis Istılahlarından Mühmel ve Sahîh-İ Buhârî Ricâlinden Süfyân'ın Tayini Meselesi, Çukurova Üniversitesi İlahiyat Fakültesi Dergisi, 18 (2), 764-795.

Öz- Temel hadis kaynaklarında, isnâdı zikrederken bazı râvîlerin kimliğini açıkça tayin etmemek musannıfların sıkça görülen tasarruflarındandır. $B u$ durum hadislerin tasnif edilmeye başlandığı hicrî II. ve III. yüz yıl gibi ilk dönemlerde yaygın olan, isnâdlar ve râvîler hakkındaki yüksek bilgi düzeyi dikkate alındığında anlaşılabilir mahiyette olmakla beraber bu sahadaki bilginin azaldığı sonraki dönemler için "isnâdın sıhhat düzeyi" problemini gündeme getirmiştir. Farklı türleri olan bu uygulamanın örneklerinden biri de "ihmâl" veya "mühmel" dir. Bu araştırmada söz konusu ıstılahın anlamı üzerinde durulmuş ve özellikle Buhârînin (ö. 256/870) Sahîh'indeki isnâdlarda yer alan iki önemli râvî, Süfyân es-Sevrî (ö. 161/778) ve Süfyân b. Uyeyne (ö. 198/814) hakkında ne ölçüde kullanıldığı ve bunları birbirinden temyiz etmenin imkânı, mezkûr eserin bazı önemli şerhleri esas alınarak belirlenmeye çalışılmıştır. Yine Süfyân'in tayini hususundaki ihtilaflar ve farklı görüşlerin gerekçeleri, bulundukları isnâdın sıhhatine doğrudan etki etmeleri nedeniyle bu râvîlerin biyografileri ve adâlet ve zabt durumları ve bu tür rivayetlerin genel olarak sıhhat açısından değeri de inceleme konusu yapılmıştır.

Anahtar sözcükler- Süfyân b. Uyeyne, Süfyân es-Sevrî, İhmâl, Mühmel, İsnâd.

\section{$\S \S \S$}

\section{Giriş}

$\mathrm{Bu}$ araştırmanın fikir olarak ortaya çıkmasının temelinde M. Fuat Sezgin'in Buharînin Kaynakları adlı eserindeki bir iddiası bulunmaktadır. Buna göre Sezgin Buhârî'nin, hangisi olduğunu belirlemeksizin mutlak olarak Süfyân demesi halinde bunun Süfyân b. Uyeyne mi yoksa Süfyân es-Sevrî mi olduğunu

\footnotetext{
* Millî Eğitim Bakanlığı Kadirli Fen Lisesi Din Kültürü ve Ahlak Bilgisi Öğretmeni, e-posta: ser-kancelikan@hotmail.com, ORCID: 0000-0001-6469-9533
} 
tayin etmenin mümkün olmadığını, çünkü her iki muhaddisin muasır olup müşterek şeyhlerden rivayet ettiklerini ifade etmiştir. ${ }^{1}$ Ancak görüldüğü kadarıyla durum bundan farklıdır. Bu vasıftaki isnâdlarda söz konusu iki muhaddisten hangisinin kastedildiğine işaret eden bazı kıstaslar bulunmaktadır ki kendilerinden çokça rivayet etmekle temayüz etmiş bulunan meşhur talebelerinin ve uzun süren birliktelikleri ve onlardan rivayetlerinin çokluğu malum olan hocalarının tespit edilmesi bunların en belirgin olanlarındandır.

Diğer tarafdan hadis şârihleri de büyük oranda, isnâdlarda veya bazı lafızların açıklanması sırasında metinlerde isimleri kaydedilen bu iki muhaddisin kimliğini tayin etmiş bulunmaktadır. Yine âlimler, hadis ıstılahları içerisinde "mühmel" kavramı ile ifade edilen bu tür râvîlerin kimliğini tayin hususunda genel olarak da bir takım ölçütler geliştirmişlerdir. Bahsi geçen iddia ile ilgili temel mesele ele alınmadan önce mezkûr ıstılahın ne anlama geldiğinin belirlenmesi konunun vuzuha kavuşması açısından önem taşımaktadır.

\section{Mühmelin Tarifi}

Mühmel, terk ve inmal etmek, başıboş bırakmak gibi anlamlara gelen $\mathrm{J}$ م-ه (h-m-l) kök harfleriyle if'âl babından ism-i mefûl olup terk ve inmal edilmiş anlamlarına gelir. Fiil olarak işini sağlam yapmama anlamı da bulunmaktadır. ${ }^{2}$

Hadis usûlü terimi olarak da bir râvî veya musannıfın sadece isimde veya baba, dede ismi, nisbet, künye ve benzerlerinde ortak olan iki farklı şahıstan, bu ortak isimlerini zikrederek hadis rivayet etmesi, ancak bu şahıslardan her birinin kendine has bir özelliğine veya ismine ve sıfatına yer vermemesi nedeniyle bunları birbirinden ayırt edilemeyecek durumda bırakmış olması "ihmâl", bu şekilde kimlikleri tayin edilmeden zikredilen râvîler de "mühmel" olarak tanımlanır. ${ }^{3}$ Râvînin veya musannıfın isnâdı haber verirken işini tam ve sağlam yapmamış olması durumu, kelimenin yukarıda kaydedilen bu yöndeki

\footnotetext{
${ }^{1}$ Sezgin, M. Fuad, Buhârînin Kaynakları, Otto Yay., Ankara 2012, s. 294.

2 İbn Manzûr, Cemalüddin Muhammed b. Mükerrem, Lisanu'I-Arab, I-VI, thk. Abdullah Ali el-Kebîr, Muhammed Ahmed Hasebullah, Hâşim Muhammed eş-Şâzelî, Seyyid Ramazan Ahmed, Dâru'lMaârif, Kahire trs., "h-m-l”, VI, 4701-4702. Ayrıca bkz. Tahânevî, Muhammed Ali, Mevsûatü keşşâfi Istılâhâti'l-funûni ve'l-ulûm, I-II, thk. Ali Dehrûc, Mektebetü Lübnan Nâşirûn, Lübnan 1996, II, 1664; Tahhân, Mahmûd, Teysîru mustalahi'l-hadîs, Mektebetü'l-Maârif, Riyâd 1432/2011, s. 258; Uğur, Mücteba, Ansiklopedik Hadis Terimleri Sözlüğü, TDV Yayınları, Ankara 1992, s. 264; Aydınlı, Abdullah, "Mühmel", DIA, İstanbul 2006, XXXI, 524.

${ }^{3}$ Bkz. İbn Hacer, Şihâbeddin Ahmed b. Ali b. Muhammed b. Ahmed Askalânî, Nüzhetü'n-nazar fî tavdîhi Nuhbeti'l-fiker fi mustalahi ehli'l-eser, thk. Nureddin Itr, Matbaatu's-Sabâh, Dımeşk 1421/2000, s. 120; Süyûtî, Celaleddin Abdurrahman, Tedrîbü'r-râvî fî şerhi Takrîbi'n-Nevevî, Dâru İbn Hazm, Beyrut 1430/2009, s. 412; Tahhân, Teysîru mustalahi'l-hadîs, s. 258; Türkî, Muhammed b. Türkî, Temyîzü'l-mühmel mine's-Süfyâneyni ve meahû vesâilü temyîzi'l-mühmeleyn, Dâru'lÂsıme, Riyad 1431/2010, s. 11; Koçyiğit, Talat, Hadîs Usûlü, Türkiye Diyanet Vakfı Yay., Ankara 2013, s. 228; Uğur, Ansiklopedik Hadis Terimleri Sözlüğü, s. 264; Aydınlı, "Mühmel”, DíA, XXXI, 524.
} 
sözlük anlamıyla doğrudan ilişkili görünmektedir. Terim, hadis usûlü ilminde genel itibariyle "muttefik ve mufterik"4 başlığı altında incelenir.

Râvînin mechûl olmasının isnâdı zayıflattığı ilk anda akla gelebilirse de bu, mühmel râvîlerden birinin sika diğerinin zayıf olduğunun bilinmesi durumunda böyledir. ${ }^{5}$ Buna örnek olarak Yahya b. Maîn'in (ö. 233/848), yalancı olduğunu ve hadislerinin yazılmaması gerektiğini belirttiği İsmail b. Ebân elGanevî ile sika olduğunu söylediği İsmail b. Ebân el-Varrâk zikredilmiştir. Yaşadıkları asır itibariyle yakın olan bu her iki râvîden de hadis yazan Yakûb b. Şeybe isnâdlarda bu şahısların kimliğini, nisbet ve lakapları gibi mümeyyiz vasıflarını kullanarak açıklamadığı ve bunları şeyhleri ve rivayetleri hakkındaki bilgiler aracılığı ile de birbirlerinden ayırmak mümkün olmadığı zaman tevakkuf etmek ve bu hadis ile ameli terk etmek gerekir. Çünkü rivayetin, mecrûh olduğu sabit olan İsmail b. Ebân el-Ganevî̀nin rivayeti olmadığından emin olunamaz. Âdil veya mecrûh olduğu bilinmeyen râvînin rivayeti ile amel etmenin caiz olmadığı ise malumdur. ${ }^{6}$

Râvîlerin her ikisinin de sika olduğunun bilinmesi durumunda ise bunun isnâdın sıhhatine zarar vermeyeceği belirtilmiştir. ${ }^{7}$ Buna örnek olarak da Buhârî'nin nisbet etmeden kaydettiği Ahmed yolu ile İbn Vehb'den rivayeti zikredilebilir. Bu râvî ya Ahmed b. Sâlih'dir ya da Ahmed b. İsa'dır. Bir başka örnek de yine Buhârî̀nin nisbet etmeden zikrettiği Muhammed yolu ile Iraklılardan rivayetidir. Bu râvî de ya Muhammed b. Selâm'dır ya da Muhammed b. Yahya ez-Zühlî'dir. ${ }^{8}$ Aynı isme sahip bu râvîlerin sika olmaları, mühmel olarak bırakılmaları nedeniyle isnâdın zayıf sayılmasına engel olarak görülmüştür.

Hatîb el-Bağdâdî'nin (ö. 463/1071) el-Kifâye'de, mühmel râvîlerden birinin âdil diğerinin fâsık olması ve bunların kimliğini tayin etmeye yarayacak bir karinenin bulunmaması durumunda rivayetin hükmünün ne olacağına dair ${ }^{9}$ bir başlık açmışken, her iki râvînin de âdil olması hakkında özel bir bölüme yer

\footnotetext{
${ }^{4}$ Muttefik ve mufterik, kendileri farklı kişiler olmakla beraber isimleri, künyeleri ve nisbeleri yazılış ve okunuş yönünden aynı olan râvîleri ifade etmekte kullanılan hadis usûlü ıstılahıdır. Bkz. Süyûtî, Tedrîbü'r-râvî, s. 407; Tahhân, Teysîru mustalahi'l-hadîs, s. 252; Koçyiğit, Talat, Hadis Terimleri Sözlüğü, Rehber Yay., Ankara 1992, s. 377; Uğur, Ansiklopedik Hadis Terimleri Sözlüğü, s. 297. ${ }^{5}$ Bu konuyla ilgili bilgi ve çeşitli örnekler için bkz. Hatîb el-Bağdâdî, Ebû Bekir Ahmed b. Ali b. Sâbit, Kitâbu'l-kifâye fî ilmi'r-rivâye, Dâiretü'l-Maârifi'l-Osmaniyye, Haydarâbâd 1357, s. 371-372.

${ }^{6}$ Hatîb el-Bağdâdî, el-Kifâye, s. 371-372.

7 İbn Hacer, Nüzhetü'n-nazar, s. 120-121.

8 İbn Hacer, Nüzhetü'n-nazar, s. 121. Ayrıca bkz. Koçyiğit, Hadîs Usûlü, s. 228. İbn Hacer bu tür râvîlerle ilgili olarak Buhârî şerhi Fethu'l-bârînnin mukaddimesinde oldukça kapsamlı bilgiler vermektedir. Bkz. İbn Hacer, Fethu'l-bârî, I, 276-297.

${ }^{9}$ Metinde de kaydedildiği üzere böyle bir rivayetin hükmü tevakkuf ve kendisiyle amelin terk edilmesidir. Bkz. Hatîb el-Bağdâdî, el-Kifâye, s. 371-372.
} 
vermemesi onun da böyle bir rivayetin sıhhatinden şüphe etmediği şeklinde yorumlanabilir. Diğer yandan birçok şârih de adalet ve zabt sıfatına sahip mühmel râvîlerin bulunduğu isnâdlar hakkındaki yorumlarında sıhhatin zarar görmediğini belirtmişlerdir.

Bu noktada araştırmanın konusu olan râvîler, Süfyân es-Sevrî̀nin ve Süfyân b. Uyeyne'nin hadis ilminin en önemli temsilcilerinden olmaları ve hadis âlimlerinin tamamına göre en yüksek güvenilirlik vasıflarına sahip bulunmaları önem kazanmaktadır. Bu durum, Buhârî'nin Sahîh'indeki bu türden rivayetlerin sıhhatine yönelik herhangi bir itiraza ${ }^{10}$ imkân vermemektedir.

Müelliflerin, eserlerinde böyle bir yöntem takip ederek bazı râvîlerin kimliğini açıkça bildirmemeleri de kendi dönemlerindeki âlimler arasında isnâdlar ve râvîler hakkında son derece geniş bir bilgi birikiminin olması nedeniyle bu yönde bir açıklamaya intiyaç duymamalarından kaynaklanmaktadır. Ne var ki bu durum eserlerin tasnif edilmeye başlandığı ilk dönemlerde sorun teşkil etmezken sonraki nesiller açısından, rivayetlerin sıhhatini tespit aşamasında bir problem olarak ortaya çıkmıştır. Nitekim daha önce de ifade edildiği üzere râvînin adalet ve zabt sıfatı hakkında kesin bir hüküm verilmesine engel olan bu durum isnâdın sıhhatini tartışmalı hale getirmişir. Netice itibariyle muhaddisler bu problemi aşma adına mühmel râvîlerin kimliğini tespit etmeye yarayacak bir takım ölçütler geliştirmişlerdir. Bunlar özetle:

1. Mühmel râvînin, talebelerini ve şeyhlerinin bilmek

2. Râvîlerin mühmel râvî ile olan ilgilerine bakmak

3. Râvîlerin vatanlarını, tabakalarını, doğum ve ölüm tarihlerini bilmek

4. Mühmel râvînin şeyhinden nasıl rivayet ettiğini, hangi eda sigalarını kullandığını bilmek

5. Nisbet edilerek zikredilmiş olması intimaline binaen mühmel râvî bulunan isnâda yakın isnâdlara bakmak

6. Mühmel râvînin rivayetin başka tariklerinde nisbesi ile zikredilmesinin çokça gerçekleşen bir durum olması nedeniyle hadisin bütün tariklerini çıkarmak

7. Mühmel râvî bulunan hadisi nakleden kitaplara bakmak

\footnotetext{
${ }^{10}$ Bazı âlimler tarafından böyle bir itirazın vaki olduğu bilgisini İbn Hacer, Kutbüddin el-Halebî’den naklen haber vermektedir. Bkz. İbn Hacer, Şihâbeddin Ahmed b. Ali b. Muhammed b. Ahmed Askalânî, Fethu'I-bârî şerhu Sahîhi'l-Buhârî, I-VIII, Dâru'l-Marife, Beyrut 2005, I, 276.
}

ÇÜiFD, 2018, cilt: 18, sayı: 2, ss. 764-795. 
8. Râvîleri mühmel olarak zikreden kitap musannıfının sıhhat şartlarını bilmek

9. Hadisin (muhteva ve nekâret durumu açısından) metnine bakmak

10. Bu yöntemlerden biri ile kimliği açığa kavuşmadığında iki râvîden en kıdemli ve meşhur olanı tercih etmek şeklindedir. ${ }^{11}$

Yukarıda güvenilirliklerine kısaca değinilen araştırma konusu iki râvî hakkında özet bilgi vermek de faydalı olacaktır. Bu özellikle Buhârî'nin Sahîh'inde mevzu bahis olan râvîlerin mühmel olarak zikredilmesinin rivayetlerin sıhhati açısından bir problem teşkil etmediğini göstermesi açısından önemlidir.

\section{Süfyân es-Sevrî (ö. 161/778):}

İsmi Süfyân b. Saîd b. Mesrûk künyesi ise Ebû Abdullah olup Kûfelidir. ${ }^{12}$ Süleyman b. Abdülmelik'in hilafeti zamanında hicrî 97 yılında doğmuştur. ${ }^{13}$ Doğduğu yılın hicrî 98 olduğu da söylenmiştir. ${ }^{14}$

Babasının teşviki ile genç yaşta ilim talebine başlamış ${ }^{15}$, Hammâd b. Ebû Süleyman (ö. 120/738), Süleyman el-A'meş (ö. 148/765), Osman el-Bettî (ö. 143/760 [?]), Fudayl b. Iyâd (ö. 187/803), Muhammed b. İshâk b. Yesâr (ö. 151/768), Ma'mer b. Râşid (ö. 153/770) gibi âlimlerden hadis rivayet etmiştir. Kendisinden rivayet edenler arasında da İsmail b. Uleyye (ö. 193/809), Bişr b. es-Seriy (ö. 227/841), Süfyân b. Uyeyne, Abdullah b. el-Mübârek (ö. 181/797), Abdurrahman b. Mehdî (ö. 198/813-14) ve aynı zamanda şeyhleri arasında da bulunan Süleyman el-A'meş vardır. ${ }^{16}$

\footnotetext{
${ }^{11}$ Kaydedilen bu ölçütler hakkındaki kapsamlı bilgiler ve örnekler için bkz. Türkî, Temyîzü’-mühmel, s. 17-50. Ayrıca bkz. Aydınlı, "Mühmel", DiA, XXXI, 524. İbn Hacer'in özellikle ilk iki madde ile ilgili görülebilecek bir değerlendirmesi için bkz. İbn Hacer, Nüzhetü’n-nazar, s. 121. Ayrıca bkz. Koçyiğit, Hadîs Usûlü, s. 228.

12 İbn Sa'd, Muhammed b. Sa'd b. Meni' ez-Zührî, Kitâbu't-tabakâti'l-kebîr, I-XI, thk. Ali Muhammed Ömer, Mektebetü'l-Hancî, Kahire 1421/2001, VIII, 492; Mizzî, Cemalüddin Ebü'l-Haccâc Yusuf, Tehzîbu'l-Kemâl fi esmâi'r-ricâl, I-XXXV, thk. Beşşâr Avvâd Maruf, Müessesetü'r-Risâle, Beyrut 1403/1983, XI, 154-155; Zehebî, Şemsüddin Muhammed b. Ahmed b. Osman, Siyeru a'lâmi'nnübelâ, I-XXIX, thk. Şuayb el-Arnaût, Ali Ebû Zeyd, Muhammed Nuaym el-Araksûsî, Müessesetü'rRisâle, Beyrut 1402/1982, VII, 229-230; İbn Hacer, Şihâbeddin Ahmed b. Ali b. Muhammed b. Ahmed Askalânî, Tehzîbu't-Tehzîb, I-IV, Müessesetü'r-Risâle, Beyrut 1995, II, 56; a.mlf. Takrîbu'tTehzîb, I-II, Dâru'l-Kütübi'l-İlmiyye, Beyrut 1415/1995, I, 371.

${ }_{13}$ İbn Sa'd, et-Tabakât, VIII, 492; Mizzî, Tehzîbu'l-Kemâl, XI, 169; Zehebî, Siyeru a'lâmi'n-nübelâ, VII, 230.

${ }^{14}$ Zehebî, Siyeru a'lâmi'n-nübelâ, VII, 242.

${ }^{15}$ Zehebî, Siyeru a'lâmi'n-nübelâ, VII, 230.

${ }^{16}$ Diğer hocalarının ve talebelerinin listesi için bkz. Mizzî, Tehzîbu’l-Kemâl, XI, 155-164; Zehebî, Siyeru a'lâmi'n-nübelâ, VII, 230-236; İbn Hacer, Tehzîbu't-Tehzîb, II, 56-57.
} 
Sika, memûn, sebt, hâfı, fakîh, âbid, imâm ve hüccet gibi ilminin yüksekliğine ve güvenilirliğine delalet eden sıfatlarla nitelendirilmiş ${ }^{17}$, muhaddisler arasında ondan daha üstününün olmadığı, kulları üzerinde Allah'ın bir hücceti olduğu yönünde övgülerde bulunulmuştur. ${ }^{18}$ Öyle ki Hatîb elBağdâdî güvenilirliği ve sağlamlığı hususunda görüş birliği olması nedeniyle tezkiyeye bile intiyaç duymadığını belirtmiştir. ${ }^{19}$

Şu'be (ö. 160/776), Süfyân b. Uyeyne, Ebû Âsım en-Nebîl (ö. 212/828), Yahya b. Maîn ve daha birçok âlim Süfyân es-Sevrînin hadis ilminde "müminlerin emiri" olduğunu söylemişlerdir. ${ }^{20}$ Yine bir kimse herhangi bir konuda Süfyân es-Sevrî̀ye muhalefet ettiğinde râcih olanın Süfyân'ın görüşü olduğu da Yahya b. Maîn'in sözü olarak nakledilmektedir. ${ }^{21}$ Ayrıca onun sadece ilimde değil zühd ve takvada da insanlara öncülük ettiği22 dünya serveti ona yöneldiği halde kendisinin ondan yüz çevirdiği söylenmiştir. ${ }^{23} \mathrm{Bu}$ anlamda olmak üzere onun şu sözü önemlidir: "Bu ilmi öğrenin! Öğrendiğinizde onu koruyun! Koruyunca kendisiyle amel edin! Amel edince de bu ilmi yayın!"24 Yine onun ifadesine göre $\mathrm{Hz}$. Peygamber'den kendisine ulaşan her bir hadis ile bir kere de olsa mutlaka amel etmiştir. ${ }^{25}$

Abbâsî halifelerinden Muhammed el-Mehdî zamanında hicrî 161 yılında Basra'da vefat ettiği hususunda görüş birliği olduğu nakledilmiştir. ${ }^{26}$

\section{Süfyân b. Uyeyne (ö. 198/814):}

İsmi Meymûn el-Hilâlî olup babasına nispetle İbn Ebû İmrân diye de anılır. Künyesi Ebû Muhammed'dir. ${ }^{27}$ Kûfe'de doğup Mekke'ye yerleşmiş ve burada vefat etmiştir. Bu nedenle her iki yere de nispet edilir. ${ }^{28}$

\footnotetext{
17 İbn Sa'd, et-Tabakât, VIII, 492; Zehebî, Siyeru a'lâmi'n-nübelâ, VII, 246, 249, 270; İbn Hacer, Tehzîbu't-Tehzîb, II, 57; a.mlf. Takrîbu't-Tehzîb, I, 371.

18 Zehebî, Siyeru a'lâmi'n-nübelâ, VII, 255.

${ }^{19}$ Mizzî, Tehzîbu'l-Kemâl, XI, 168-169; İbn Hacer, Tehzîbu't-Tehzîb, II, 57.

${ }^{20}$ Mizzî, Tehzîbu'l-Kemâl, XI, 164; Zehebî, Siyeru a'lâmi'n-nübelâ, VII, 236; İbn Hacer, Tehzîbu'tTehzîb, II, 57.

${ }^{21}$ Mizzî, Tehzîbu'l-Kemâl, XI, 166; Zehebî, Siyeru a'lâmi'n-nübelâ, VII, 237, 240; İbn Hacer, Tehzîbu't-Tehzîb, II, 57.

${ }_{22}$ Mizzî, Tehzîbu'l-Kemâl, XI, 167, 169; Zehebî, Siyeru a'lâmi'n-nübelâ, VII, 240, 241; İbn Hacer, Tehzibu't-Tehzîb, II, 57.

${ }^{23}$ Zehebî, Siyeru a'lâmi'n-nübelâ, VII, 257.

24 İbn Sa'd, et-Tabakât, VIII, 492.

25 Zehebî, Siyeru a'lâmi'n-nübelâ, VII, 242.

26 İbn Sa'd, et-Tabakât, VIII, 492; Mizzî, Tehzîbu'l-Kemâl, XI, 169; Zehebî, Siyeru a'lâmi'n-nübelâ, VII, 279; İbn Hacer, Tehzîbu't-Tehzîb, II, 57; a.mlf. Takrîbu't-Tehzîb, I, 371.

27 İbn Sa'd, et-Tabakât, VIII, 59; Mizzî, Tehzîbu'l-Kemâl, XI, 177-178; Zehebî, Siyeru a'lâmi'nnübelâ, VIII, 454; İbn Hacer, Tehzîbu't-Tehzîb, II, 59; a.mlf. Takrîbu't-Tehzîb, I, 371.

${ }_{28}$ Mizzî, Tehzîbu'l-Kemâl, XI, 177-178; Zehebî, Siyeru a'lâmi'n-nübelâ, VIII, 454; İbn Hacer, Tehzîbu't-Tehzîb, II, 59; a.mlf. Takrîbu't-Tehzîb, I, 371.
} 
Bizzat kendisinden nakledilen bilgiye göre hicrî 107 senesinde Şaban ayının ortasında doğmuştur. ${ }^{29}$ Hadis öğrenmeye çok genç yaşta hatta çocuk iken başladığı nakledilmektedir. ${ }^{30} 142$ senesinde henüz 35 yaşında iken de kendisinden hadis yazılmaya başlanmıştır. ${ }^{31}$

Abdullah b. Dînâr (ö. 127/744), Ma'mer b. Râşid, Şu'be b. el-Haccâc, Süfyân es-Sevrî, Yahya b. Saîd el-Ensârî (ö. 143/760), Muhammed b. Müslim b. Şihâb ez-Zührî (ö. 124/742) gibi birçok önemli âlimden hadis rivayet ettiği gibi kendisinden de birçok muhaddis rivayette bulunmuştur. Bunlara da Abdurrahman b. Mehdî, Vekî b. el-Cerrâh (ö. 197/812), Abdurrezzak b. Hemmâm (ö. 211/826-27), Yahya b. Saîd el-Kattân (ö. 198/813), Yahya b. Maîn ve aynı zamanda şeyhi de olan Süfyân es-Sevrî örnek verilebilir. ${ }^{32}$

Sika, sebt, hâfız, fakîh, imâm ve hüccet gibi ilminin büyüklüğüne ve güvenilirliğine delalet eden vasıflarla nitelendirilmiştir. ${ }^{33}$ Bilhassa İbn Şihâb ezZührî'den ve Amr b. Dînâr'dan rivayet edenler arasında en sağlam ve güvenilir kimse olduğu nakledilmektedir. ${ }^{34}$ İlmî konumu ile ilgili olarak İmâm Şâfiî'den nakledilen bir söz oldukça önemlidir. Buna göre Hicâz ilminin kaybolup gitmesini engelleyen iki âlim vardır ki biri İmâm Mâlik diğeri de Süfyân b. Uyeyne'dir. ${ }^{35}$ Yine İmâm Şâfiî 6 hadis dışında ahkâm hadislerinin tamamını onda bulduğunu belirtmiştir. ${ }^{36}$ Onun, hadis ilmindeki sağlamlığı nedeniyle tezkiyeye ihtiyacı olmadığı da söylenmiştir. ${ }^{37}$

Bazı rivayetler Süfyân b. Uyeyne'nin ilmi ile amel eden zühd ve takva sahibi bir âlim olduğunu da göstermektedir. ${ }^{38}$ Onun şu sözünün buna delalet ettiği söylenebilir: "Âlim, hayrı ve şerri sadece bilen kimse değildir. Âlim ancak o kimsedir ki hayrı bilir ve ona tabi olur, şerri bilir ve ondan kaçınır." Bir başka sözünde de insana fayda vermeyen ilmin ona zarar vereceğini ifade etmiştir. ${ }^{39}$

\footnotetext{
29 İbn Sa'd, et-Tabakât, VIII, 59; Mizzî, Tehzîbu'l-Kemâl, XI, 196; Zehebî, Siyeru a'lâmi’n-nübelâ, VIII, 455, 474; İbn Hacer, Tehzîbu't-Tehzîb, II, 59-60.

${ }^{30}$ Zehebî, Siyeru a'lâmi'n-nübelâ, VIII, 455.

${ }^{31}$ Mizzî, Tehzîbu'l-Kemâl, XI, 188; İ̉n Hacer, Tehzîbu't-Tehzîb, II, 60.

32 Diğer hocalarının ve talebelerinin listesi için bkz. Mizzî, Tehzîbu'l-Kemâl, XI, 178-188; Zehebî, Siyeru a'lâmi'n-nübelâ, VIII, 455-457; İbn Hacer, Tehzîbu't-Tehzîb, II, 59.

33 İbn Sa'd, et-Tabakât, VIII, 60; Zehebî, Siyeru a'lâmi'n-nübelâ, VIII, 458, 464, 466; İbn Hacer, Tehzîbu't-Tehzîb, II, 60, 61; a.mlf., Takrîbu't-Tehzîb, I, 371.

${ }^{34}$ Mizzî, Tehzîbu'l-Kemâl, XI, 189; Zehebî, Siyeru a'lâmi'n-nübelâ, VIII, 458; İbn Hacer, Tehzîbu'tTehzîb, II, 60, 61; a.mlf., Takrîbu't-Tehzîb, I, 371.

${ }^{35}$ Mizzî, Tehzîbu'l-Kemâl, XI, 189; Zehebî, Siyeru a'lâmi'n-nübelâ, VIII, 457; İbn Hacer, Tehzîbu'tTehzîb, II, 60. Abdurrahman b. Mehdî de Hicâz ehlinin hadislerini en iyi bilen kimsenin Süfyân b. Uyeyne olduğunu söylemiştir. İbn Hacer, Tehzîbu't-Tehzîb, II, 61.

${ }^{36}$ Zehebî, Siyeru a'lâmi'n-nübelâ, VIII, 457.

37 İbn Hacer, Tehzîbu't-Tehzîb, II, 61.

${ }^{38}$ Bu husus İbn Hibbân tarafından da dile getirilmiştir. Bkz. İbn Hacer, Tehzîbu't-Tehzîb, II, 61.

${ }^{39}$ Mizzî, Tehzîbu'l-Kemâl, XI, 191-192; Siyeru a'lâmi'n-nübelâ, VIII, 462.
} 
Tedlis yaptığı da söylenilmekle beraber bunun kendisine göre sika olan râvîlerden olduğu belirtilmiştir. ${ }^{40}$ Yahya b. Maîn'den nakledildiğine göre Süfyân b. Uyeyne 197 senesinde intilâta uğramıştır ve bu ve bundan sonraki yıllarda her kimin ondan bir semâı varsa bunun hiçbir değeri yoktur. ${ }^{41}$ Ancak bu görüşün münker olduğu, sahîh ve doğru bulunmadığı da ifade edilmiştir. ${ }^{42}$

Receb Ayının, Cumartesine denk gelen ilk gününde, hicrî 198 yılında vefat etmiştir. ${ }^{43}$

IV. Buhârî'nin Sahîh'indeki İsnâdlarda Yer alan Süfyân'ın Tayini ve Konu İle İlgili İhtilaflar

Buhârî'nin, Sahîh'indeki isnâdlarda zikretmiş olduğu Süfyân'ın, es-Sevrî mi yoksa İbn Uyeyne mi olduğu meselesinin bazı şârihler tarafından büyük oranda inceleme konusu yapıldığına ve somut bir takım sonuçlara ulaşıldığına yukarıda işaret edilmişti. Bu noktada bilhassa Bedreddin el-Aynî'nin (ö. 855/1451) diğer şârihlere nispetle konuyla daha ciddi düzeyde ilgilendiği tespit edilmiştir. Bu onun genel olarak bütün râvîlerin kimliğini tayin etme çabası hususunda şerhinde takip ettiği metotla da ilgili görünmektedir. Neticede tamamına yakın sayılabilecek bir oranda, mühmel olarak bırakılan mezkûr râvînin kimliği herhangi bir şüphe ve tereddüt ifadesi gösterilmeden belirlenmiştir. Bununla beraber Aynînnin bazı isnâdların tahlili esnasında konuyla ilgili bir açıklama yapmadığı da olmuştur. Yine sınırlı sayıda olduğu söylenebilecek bazı isnâdlarda râvîyi tayin hususunda intilafların vaki olduğu da görülmektedir.

Öncelikle Buhârî'nin el-Câmiu's-sahîh'inin metninde yaptığımız taramada toplam olarak 875 isnâdda Süfyân isminin Buhârî tarafından mühmel olarak bırakıldığı belirlenmiştir. Aynî'nin Umdetü'l-kârî şerhu Sahîhi'l-Buhârî isimli şerhi temel alınarak yaptığımız taramada ise tespit edebildiğimiz kadarıyla Buhârî, Süfyân b. Uyeyne'nin ismini 524 yerde, Süfyân es-Sevrînin ismini ise 289 yerde mühmel bırakmıştır. Sahîh'in 5474 numaralı hadisinin ${ }^{44}$

\footnotetext{
40ZZehebî, Siyeru a'lâmi'n-nübelâ, VIII, 465; İbn Hacer, Takrîbu’t-Tehzîb, I, 371.

${ }^{41}$ Mizzî, Tehzîbu'l-Kemâl, XI, 196; Zehebî, Siyeru a'lâmi'n-nübelâ, VIII, 465; İbn Kesîr, Ebu'l-Fidâ el-Hâfız İmâdüddîn İsmail b. Ömer, el-Bâisü'l-hasîs şerhu Ihtisâri ulûmi'l-hadîs, thk. Ahmed Muhammed Şâkir, Dâru'l-Fikr, Beyrut 1416/1996, s. 170; İbn Hacer, Tehzîbu't-Tehzîb, II, 60; a.mlf., Takrîbu't-Tehzîb, I, 371; Süyûtî, Tedrîbü'r-râvî, s. 450.

42 Zehebî, Siyeru a'lâmi'n-nübelâ, VIII, 465.

${ }^{43}$ İbn Sa'd, et-Tabakât, VIII, 59-60; Mizzî, Tehzîbu'l-Kemâl, XI, 196; Zehebî, Siyeru a'lâmi'n-nübelâ, VIII, 470; İbn Hacer, Tehzîbu't-Tehzîb, II, 60, 61; a.mlf., Takrîbu't-Tehzîb, I, 371.

${ }^{44}$ Buhârî, Muhammed b. İsmail, el-Camiu's-sahîh, Dâru's-Selâm, Riyad 1999, Akîka 4, no: 5474.
} 
isnâdındaki, Aynî tarafından işaret edilen ihtilaf ${ }^{45}$ Süfyân b. Uyeyne ile Süfyân b. Hüseyn arasında olduğu için yukarıdaki sayıya dâhil edilmemiştir. Ancak İbn Hacer'in (ö. 852/1449) herhangi bir ihtilaftan bahsetmediği ve bu râvîyi Süfyân b. Uyeyne olarak tayin ettiği de belirtilmelidir. ${ }^{46}$

Mevzu bahis olan inmâl, ekseriyetle isnâdda olmakla beraber metin içindeki bazı açıklamalarda veya farklı isnâdlara işaret ederken de geçmektedir. Bu tasnifte Aynî'nin görüşlerinin belirleyici olması yukarıda da temas edildiği üzere onun diğer şârihlere kıyasla râvîlerin kimliklerini açıklama konusundaki hassasiyeti ve çabası ile ilgilidir. Ancak Aynînnin söz konusu râvî ile ilgili herhangi bir bilgi vermediği yerler de vardır ki bunların sayısı tespit edebildiğimiz kadarıyla 45'dir. Yine bazı yerlerde Aynînin konuyla ilgili intilaflardan bahsettiği görülmüştür ki bunların sayısı belirleyebildiğimiz kadarıyla toplam olarak 17'dir. Aynî'nin Süfyân'ın kimliği ile ilgili olarak tercih edilen hükmü temellendirmeye çalıştığı yerler de bulunmaktadır ki bunların sayısı da 13 olarak belirlenmiştir.

Ayrıca Buhârî'nin 8 yerde Süfyân b. Uyeyne'nin ismini, ismi ve künyesiyle beraber tasrih ettiği ve 99 yerde de sadece İbn Uyeyne künyesi ile birlikte kaydettiği görülmüştür. Yine Buhârî görüldüğü kadarıyla 3 yerde Süfyân esSevrî'yi ismi ve nisbesi ile beraber, 7 yerde de sadece es-Sevrî nisbesi ile kaydetmiştir. Ancak bunlar isimlerin tasrih edilmiş olması nedeniyle mühmel sayılamayacağı için yukarıda kaydedilen genel toplama dâhil edilmemiştir.

Takdir edilecektir ki belirlemiş olduğumuz ve yukarıda sayılarını zikrettiğimiz isnâdların ve rivayetlerin tek tek tahlil edilmesi ve kaydedilmesi, bir makalenin hacmini fazlasıyla aşması bakımından uygun değildir. Bu nedenle konuyla ilgili olarak varılan hükümlerin temellendirildiği veya bazı ihtilafların bulunduğu toplam 30 rivayet ve isnâdları Sahîh'deki sırasına göre incelenecektir. İbn Hacer'in Fethu'l-bârî şerhu Sahîhi'l-Buhârî ve Kirmânî'nin (ö. 786/1384) el-Kevâkibu'd-derârî fî şerhi Sahîhi'l-Buhârî isimli şerhlerinden de istifade edilerek incelenecek olan bu rivayetleri şöyle sıralamak mümkündür:

1.

عن ابن مسعود قال كان النبي صلى الله عليه وسلم يتخولنا بالموعظة في الأيام كراهة السآمة علينا

\footnotetext{
45 Aynî, Ebû Muhammed Bedruddin Mahmûd b. Ahmed b. Musa Hanefî, Umdetü'l-kârî şerhu Sahîhi'I-Buhârî, I-XXV, tsh. Abdullah Mahmûd Muhammed Ömer, Dâru'I-Kütübi'l-IIImiyye, Beyrut 1421/2001, XXI, 133.

46 İbn Hacer, Fethu'l-bârî, VI, 628.
} 
İbn Mesûd'dan nakledildiğine göre o, “Hz. Peygamber (a.s.) bizlere bıkkınlık gelmesini istememesi nedeniyle vaaz ve ilim sohbetleri için bizim durumumuza uygun zamanlar gözetirdi." demiştir. ${ }^{47}$

Rivayetin, "Muhammed b. Yusuf- Süfyân- el-A'meş- Ebû Vâil- Ibn Mesûd." şeklindeki isnâdında yer alan Süfyân'ın kimliği hakkında farklı intimaller olduğu görülmektedir ki Şârih Aynî bu râvînin Süfyân es-Sevrî olduğunu belirttikten sonra muhtemel bir itiraza da yer vermektedir. Buna göre hadisi Süfyân es-Sevrî'den nakleden Muhammed b. Yusuf el-Firyâbî (ö.212/827) aynı zamanda Süfyân b. Uyeyne'den de hadis rivayet etmiştir. Bu durumda isnâddaki muhaddisin Süfyân es-Sevrî olduğunu tercih ettiren gerekçe nedir? Aynî bu soruya, Firyâbî'nin her iki Süfyân'dan da nakletmiş olmasına rağmen mutlak olarak Süfyân dediğinde bununla Süfyân es-Sevrî̀yi kastettiğini belirterek cevap vermiştir. ${ }^{48} \mathrm{Bu}$ bilgi ile beraber düşünüldüğünde İbn Hacer'in verdiği bir başka bilgi de söz konusu râvînin Süfyân es-Sevrî olduğunu göstermektedir. Buna göre Buhârî mutlak olarak Muhammed b. Yusuf dediği zaman, her ne kadar Muhammed b. Yusuf el-Bîkendî'den de (ö. ?) rivayet etmiş olsa da, bununla sadece el-Firyâbî'yi kasteder. Dolayısıyla bu isnâddaki râvînin el-Bîkendî olduğunu zannedenler yanılmıştır. ${ }^{49}$ Fakat Kirmânînin görüşü buna muhalif olup Buhârî'nin şeyhi olan râvînin Muhammed b. Yusuf el-Bîkendî ve bunun da şeyhinin Süfyân b. Uyeyne olduğu yönündedir. 50 Diğer yandan İbn Hacer'in kaydettiğine göre bu hadisi Ahmed b. Hanbel (ö. 241/855) Müsned'inde ${ }^{51}$ İbn Uyeyne'den rivayet etmiştir. ${ }^{52}$ Şuayb el-Arnaût'un düştüğü not da bu râvînin İbn Uyeyne olduğu yönündedir. ${ }^{53}$ Müsned'deki isnâdın Süfyân'ın üst tarafındaki kısmının yukarıda kaydedilen Buhârî isnâdı ile aynı olduğu da dikkate alındığında râvînin kimliğini tayin zor görünmektedir. Fakat rivayeti her iki Süfyân'ın da naklettiği düşüncesi çözüm olarak görülebilir.

2.

عن أبي جحيفة قال قلت لعلي بن أبي طالب هل عندكم كتاب قال لا إلا كتاب الله أو فهم أعطيه رجل

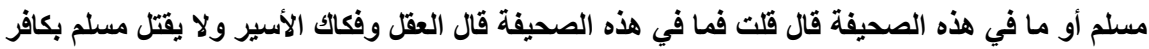

\footnotetext{
${ }^{47}$ Buhârî, İlim 11, no: 68 .

${ }^{48}$ Aynî, Umdetü'l-kârî, II, 66. Ayrıca bkz. İbn Hacer, Fethu'l-bârî, I, 618.

49 İbn Hacer, Fethu'I-bârî, I, 618. Aynî de bu râvînin el-Bîkendî olduğu görüşünü Kirmânî̀ye isnâd ettikten sonra bunun bir yanılgı olduğunu söylemiştir. Bkz. Aynî, Umdetül-kârî, II, 66.

${ }^{50}$ Kirmânî, Muhammed b. Yûsuf b. Ali b. Saîd Şemsüddin, el-Kevâkibu'd-derârî fî şerhi Sahîhi'l-

Buhârî, I-XXV, Dâru İhyâi't-Turâsi'l-Arabî, Beyrut 1401/1981, II, 32.

${ }^{51}$ Ahmed, Müsned, VI, 57, no: 3581.

52 İbn Hacer, Fethu'l-bârî, I, 618.

${ }^{53}$ Ahmed, Müsned, VI, 57, no: 3581.
} 
Ebû Cuhayfe'den nakledildiğine göre o Ali b. Ebû Tâlib'e, "Sizin yanınızda (Rasûlullah'tan kalan) bir kitâb (yazılı bir vesika) var mıdır?" diye sordu. Ali de, "Hayır! Bizde Allah'ın Kitâbı, müslüman kişiye verilen anlayış ve bir de şu sahîfede olanların dışında hiçbir şey yoktur." cevabını verdi. Ebû Cuhayfe, "Bu sahîfede ne var?' diye sorunca da Ali, "Onda diyetin, esiri kurtarmanın ve kâfir karşılığında müslümanın öldürülemeyeceğinin hükmü vardır." dedi. ${ }^{54}$

Rivayetin, "Muhammed b. Selâm- Vekî- Süfyân- Mutarrif- eş-Şa'bî- Ebû Cuhayfe." şeklindeki isnâdında yer alan Süfyân hakkında da ihtilaf söz konusudur ki Kirmânî isnâddaki râvîlerden Vekî'nin her iki Süfyân'dan da rivayet etmiş olması ve bunların da üst taraflarındaki râvî Mutarrif'den nakletmiş olmaları sebebiyle iki Süfyân'dan herhangi birinin kastedilmiş olmasını ihtimal dâhilinde görür. Ancak yine onun ifadesiyle bu belirsizlik isnâdı zayıflatmaz. Çünkü bu iki muhaddis de Buhârî'nin sıhhat şartlarına uygun olarak hadiste imam, hıfzı ve zabtı tam, adalet sıfatına sahip ve ilimde şöhretleri olan kimselerdir. ${ }^{55}$ Mühmel râvîlerin sika olması durumunda isnâdın zarar görmeyeceği şeklindeki bu düşüncenin hadis usûlünde bir ilke olarak yerleştiğine yukarıda işaret edilmişti.

Aynî'nin belirttiğine göre bazı âlimler de söz konusu isnâddaki Süfyân'ın Süfyân es-Sevrî olduğunu söylemişlerdir ki56 İbn Hacer onlardan biridir. Çünkü Vekî ondan rivayet etmekle meşhurdur ve şayet bu İbn Uyeyne olsaydı Vekî rivayeti ona açıkça nispet ederdi. Yine İbn Hacer'in belirttiğine göre aynı isimli râvîlerden rivayet edenler ile ilgili olarak kural kendisinden çokça rivayet etmek vb. bir özellik sebebiyle adı açıkça söylenmeyen râvîye hamletmektir. Vekî'nin ise Süfyân es-Sevrî'den değil Süfyân b. Uyeyne'den rivayeti azdır. ${ }^{57}$ Kirmânî'nin kaydettiğine göre hadis Yezîd el-Adenî tarafından da Süfyân esSevrî'den rivayet edilmiştir. ${ }^{58}$

Aynî ise bu zikredilenlerin, Vekî'nin her iki Süfyân'dan da rivayet ettiği ve bunların da Mutarrif'den rivayet ettiği sabit olduktan sonra mezkûr isnâddaki Süfyân'ın Süfyân es-Sevrî olmasını tercih için uygun olmadığını belirtmiştir. ${ }^{59}$ Üstelik Ebû Mesûd ed-Dımeşkî de el-Etrâf da60 bu râvî'nin Süfyân b. Uyeyne

\footnotetext{
${ }^{54}$ Buhârî, İlim 39, no: 111.

${ }^{55}$ Kirmânî, el-Kevâkibu'd-derârî, II, 118. Ayrıca bkz. Aynî, Umdetü'l-kârî, II, 239.

${ }^{56}$ Aynî, Umdetül-kârî, II, 239.

${ }^{57}$ İbn Hacer, Fethu'I-bârî, I, 654. Ayrıca bkz. Aynî, Umdetü'l-kârî, II, 239.

${ }^{58}$ Kirmânî, el-Kevâkibu'd-derârî, II, 118

${ }^{59}$ Aynî, Umdetü'l-kârî, II, 239.

60 Yapılan araştırma sonucunda bu eserin şu an mevcut ve matbu olup olmadığı konusunda bir bilgiye ulaşılamamıştır.
} 
olduğunu söylemiştir. ${ }^{61}$ Yine Kirmânî'nin de işaret ettiği üzere el-Gassânî de Takyîdu'l-mühmel'de bu hadisin İbn Uyeyne'den mahfûz olduğunu belirtmiş fakat Buhârî buna dikkat çekmemiştir. ${ }^{62}$ Konuyla ilgili bu farklı görüşlere bakılarak rivayetin her iki râvîden de nakledilmiş olmasının muhtemel olduğu söylenebilir.

3.

عن ابن عباس قال توضأ النبي صلى الله عليه وسلم مرة مرة

İbn Abbâs'dan nakledildiğine göre o, "Hz. Peygamber (a.s.) abdest alırken azalarını birer kere yıkadı." demiştir. ${ }^{63}$

Rivayetin, "Muhammed b. Yusuf- Süfyân-Zeyd b. Eslem- Atâ b. YesârIbn Abbâs." şeklindeki isnâdında yer alan Süfyân'ın da hangisi olduğu malum değildir. Kirmânî'nin belirttiğine göre Buhârînnin şeyhi Muhammed b. Yusuf ya el-Bîkendî'dir ki bu takdirde onun şeyhi de Süfyân b. Uyeyne olur. Ya da Muhammed b. Yusuf el-Firyâbî'dir ki buna göre de şeyhi Süfyân es-Sevrî'dir. Çünkü ekseriyetle el-Bîkendî İbn Uyeyne'den, el-Firyâbî ise es-Sevrî'den rivayet etmektedir. Fakat bu isnâdda el-Firyâbî'nin İbn Uyeyne'den rivayetinin kastedilmiş olma ihtimali de vardır. Çünkü isnâddaki diğer râvî Zeyd b. Eslem'in (ö. 136/754) iki Süfyân'ın şeyhi ve yine iki Muhammed b. Yusuf'un Buhârî'nin şeyhleri olması gibi her iki Süfyân da el-Firyâbî'nin şeyhleridir. Kirmânî, bu isnâdda râvînin mechûl kalması sonucuna götüren bir şüphe nedeniyle tedlîs bulunduğu ve bunun da isnâdın zayıf sayılmasını gerektirdiği söylenirse buna cevap olarak böyle durumlarda hangisi olursa olsun her iki râvînin de Buhârî'nin şartlarına göre âdil ve zâbıt olması nedeniyle bunlardaki farklılığın hükümde farklılığı gerektirmeyeceğini söyler ki ${ }^{64}$ bunun bir kural olarak görüldüğüne daha önce değinilmişti. Aynî de râvî ile ilgili bu belirsizliğe işaret etmekle beraber râcih olanın, Ebû Nuaym'ın da (ö. 430/1038) kitabında tasrih etmiş olması nedeniyle Süfyân es-Sevrî olduğunu söylemiştir. ${ }^{65}$ Bu râvînin Süfyân es-Sevrî olduğu konusunda İbn Hacer'in ise hükmü kesindir. Çünkü rivayeti ondan nakleden el-Bîkendî değil el-Firyâbî'dir. 66 el-Firyâbî'nin mutlak olarak Süfyân dediğinde bununla es-Sevrî̀yi kastettiğine ise yukarıda işaret edilmişti. Ne var ki Aynî ismini vermeden İbn Hacer'in râvîlerin kimliği ile ilgili kesin hüküm

\footnotetext{
61 İbn Hacer, Fethu'l-bârî, I, 654. Ayrıca bkz. Aynî, Umdetü'l-kârî, II, 239.

62 Kirmânî, el-Kevâkibu'd-derârî, II, 118; Aynî, Umdetü'l-kârî, II, 239.

${ }^{63}$ Buhârî, Vudû 22, no: 157.

${ }^{64}$ Kirmânî, el-Kevâkibu'd-derârî, II, 206. Ayrıca bkz. Aynî, Umdetü'l-kârî, III, 3.

${ }^{65}$ Aynî, Umdetül-kârî, III, 3.

66 İbn Hacer, Fethu'l-bârî, I, 699.
} 
vermesini eleştirir ve bunu delilsiz bir iddia olarak değerlendirir. Ona göre Kirmânî'nin zikrettiği ihtimaller henüz çürütülmüş değildir. ${ }^{67}$

4. Kitâbu'l-Vudû'un 33. Babında Buhârî'nin muallak olarak zikrettiği bazı fıkhî görüşlere dair bir bölüm de şöyledir:

قال الزهري إذا ولغ الكلب في إناء ليس له وضوء غيره يتوضأ به وقال سفيان هذا الفقه بعينه يقول

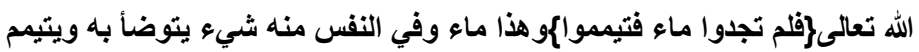

Zührî, "Köpek, su kabını yaladığı ve abdest alacak olan kimse için bu kaptakinden başka su da bulunmadığı zaman bu su ile abdest alır." dedi. Bu görüş hakkında Süfyân da şöyle demiştir: "Bu hüküm aynıyla Kur'ân'daki hükümdür ki buna göre Allah (c.c.) şöyle demiştir: 'Su bulamazsanız tertemiz bir toprakla teyemmüm edin!' (Nisâ, 4/43). İşte bu da bir su olmakla beraber gönülde onun hakkında bir tereddüt vardır. Bu nedenle kişi bu su ile abdest alır sonra da teyemmüm eder."68

Kaydedilen bu bölümde yorumu muallak olarak zikredilen Süfyân'ın da Süfyân es-Sevrî olduğu Kirmânî'ye göre açıktır. ${ }^{69}$ İbn Hacer ve Aynî'nin ifadelerine göre de bu râvî Süfyân es-Sevrî'dir. Onlar bu görüşlerinin dayanağı olarak Velîd b. Müslim'in (ö. 195/810), Musannefinde Zührî’nin bu görüşünü naklettikten sonra, "Bunu Süfyân es-Sevrî̀ye söyledim." diyerek ismini tasrih etmiş olmasını gösterirler. Yine İbn Hacer ve Aynî'nin belirttiklerine göre bu tasrih olmasa akla ilk gelen bu râvînin Süfyân es-Sevrî değil, Zührî'den rivayetle maruf olması nedeniyle Süfyân b. Uyeyne olduğudur. ${ }^{70}$

5.

حثثي عمرو بن عامر عن أنس قال كان النبي صلى الله عليه وسلم يتوضأ عند كل صلاة قلت كيف

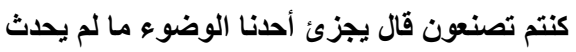

Amr b. Âmir'in Enes'den rivayet ettiğine göre Hz. Peygamber (a.s.) her namaz için abdest almaktaydı. Amr'ın Enes'e, "Peki siz nasıl yapıyordunuz?" diye sorması üzerine Enes, "Abdestimizi bozmadığımız sürece bize bir abdest yetiyordu." dedi. ${ }^{71}$

Aynî rivayetin, "Muhammed b. Yusuf- Süfyân- Amr b. Âmir- Enes." ve "Müsedded- Yahya- Süfyân- Amr b. Âmir- Enes." şeklindeki isnâdlarında bulunan Süfyân'ın Süfyân es-Sevrî olduğunu çünkü Süfyân b. Uyeyne'nin

\footnotetext{
${ }^{67}$ Aynî, Umdetü'l-kârî, III, 3.

${ }^{68}$ Buhârî, Vudû 33, Muallak.

${ }^{69}$ Kirmânî, el-Kevâkibu'd-derârî, III, 6.

70 İbn Hacer, Fethu'l-bârî, I, 711; Aynî, Umdetü'l-kârî, III, 54.

${ }^{71}$ Buhârî, Vudû 54, no: 214.
} 
üstteki râvî Amr b. Âmir'den rivayetini bulamadığını belirtmiştir. ${ }^{72}$ İbn Hacer de muhtemelen ilk isnâddaki, Buhârî'nin şeyhi olan râvînin Muhammed b. Yusuf el-Firyâbî olduğu düşüncesinden hareketle Süfyân'ın da es-Sevrî olduğunu söylemiştir. ${ }^{73}$ Aynı şekilde Kirmânî de her iki isnâdda bulunan Süfyân'ın esSevrî olduğunu söylemiş ve ikinci isnâdın zikredilmesinde bazı faydalar bulunduğunu belirtmiştir. Bunlardan birine göre Buhârî, Süfyân'ın müdellis bir râvî olması ve müdellisin de semâı bir başka tarikden sabit olmadığı sürece kendisiyle inticâc edilememesi nedeniyle semâın tasrih edildiği ikinci tariki Zikretmiştir (يحيى عن سفيان قال حدثني عمرو بن عامر).74

6.

$$
\text { عن أنس قال بزق النبي صلى الله عليه وسلم في ثوبه }
$$

Enes'den nakledildiğine göre o Hz. Peygamber'in (a.s.), (namaz esnasında tükrüğü kendisine galebe eden kimsenin ön ve sağ tarafına değil sol tarafına veya ayaklarının altına tükürmesi gerektiğini bildirdiğini veya bir başka seçeneği göstermek ve öğretmek üzere) elbisesinin içine tükürdüğünü söylemiştir. 75

Rivayetin, "Muhammed b. Yusuf (el-Firyâbî)- Süfyân- Humeyd- Enes." şeklindeki isnâdında yer alan Süfyân'ın da Süfyân es-Sevrî olduğu Mizzî (ö. 742/1342), Kirmânî ve Aynî tarafından belirtilmiştir. ${ }^{76}$ Aynî ayrıca Dârekutnî'nin de (ö. 385/995) bunu tasrih ettiğini söylemiştir. Buna göre Dârekutnî bu hadisin râvîlerini zikrettiği zaman "Bunu Süfyân b. Saîd (es-Sevrî) Humeyd'den rivayet etti." demiş ve Süfyân b. Uyeyne'yi zikretmemiştir. Ayrıca el-Firyâbî, Süfyân esSevrî ile birlikteliği çok olan bir râvîdir. Diğer taraftan el-Ceyyânî ve bazı âlimler Muhammed b. Yusuf el-Bikendî'nin Süfyân b. Uyeyne'den naklettiklerinden bahsederken söz konusu rivayeti onun nakli olarak zikretmemişlerdir. Yine İbn Uyeyne'nin Humeyd'den rivayeti azdır. Öyle ki Buhârî ondan rivayet ettiği sadece bir hadisi tahric etmiştir. ${ }^{77}$ İbn Hacer'in kaydettiğine göre de mezkûr râvî

\footnotetext{
72 Aynî, Umdetü'l-kârî, III, 167.

73 İbn Hacer, Fethu'l-bârî, I, 746.

${ }^{74}$ Kirmânî, el-Kevâkibu'd-derârî, III, 62.

${ }^{75}$ Buhârî, Vudû 70, no: 241.

${ }^{76}$ Mizzî, Cemalüddin Ebu'l-Haccâc Yusuf b. Abdurrahman, Tuhfetü'l-eşrâf bi-ma'rifeti'l-etrâf, I-XIII, thk. Abdüssamed Şerefüddin, el-Mektebetü'I-İslâmî/ed-Dâru'l-Kayyime, byy. 1403/1983, I, 190, no: 674; Kirmânî, el-Kevâkibu'd-derârî, III, 100; Aynî, Umdetü'l-kârî, III, 263.

${ }^{77}$ Aynî, Umdetü'l-kârî, III, 263.
} 
Süfyân es-Sevrî'dir. Nitekim hadisi ondan nakleden râvî de Ebû Nuaym'ın elMüstahrec'inde ${ }^{78}$ rivayet ettiği üzere Muhammed b. Yusuf el-Firyâbî'dir. ${ }^{79}$

7.

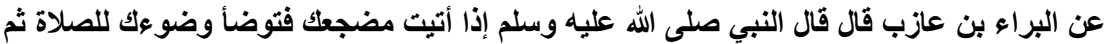

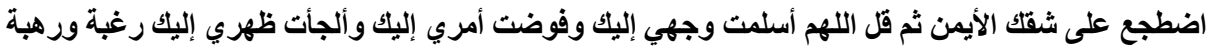

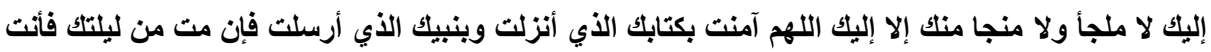

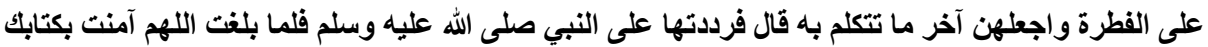

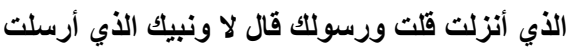

Berâ b. Âzib'den nakledildiğine göre o, Hz. Peygamber'in (a.s.) kendisine şöyle dediğini söylemiştir: "Yatacağın zaman namaz için abdest aldığın gibi abdest al! Sonra sağ tarafın üzerine yat! Sonra da, 'Allahım! Kendimi sana teslim ettim. İşimi sana bıraktım. Sırtımı sana dayadım. Ümit ederek ve korkarak sana yöneldim. Senden sığınılıp güvende olunacak yer sadece sensin. Allahım! Indirdiğin kitabına ve gönderdiğin peygamberine iman ettim.' de! Eğer bu gece ölecek olursan fitrat üzere ölürsün. Bunlar son sözlerin olsun!" Berâ devamla şöyle dedi: "Ben bu sözleri Hz. Peygamber'e (a.s.) tekrar ettim. 'Allahım! Indirdiğin kitabına iman ettim.' dedikten sonra 'Gönderdiğin rasûlüne.' dedim. Hz. Peygamber, 'Hayır! Gönderdiğin nebîne.' dedi."

Rivayetin, "Muhammed b. Mukâtil- Abdullah- Süfyân-Mansûr- Sa'd b. Ubeyde- el-Berâ b. Âzib." şeklindeki isnâdında yer alan Süfyân da İbn Hacer ve Aynî'nin ifadelerine göre Süfyân es-Sevrî'dir. ${ }^{81}$ Ancak Kirmânî, Süfyân esSevrî gibi Süfyân b. Uyeyne olmasının da muhtemel olduğunu söylemiştir. Çünkü Abdullah b. el-Mübârek her ikisinden de rivayet etmiş olup bu ikisi de Mansûr'dan rivayet etmişlerdir. Fakat daha açık olan bunun Süfyân es-Sevrî olduğudur. Nitekim âlimler, Mansûr'dan rivayette en sağlam ve güvenilir olanın Süfyân es-Sevrî olduğunu söylemişlerdir. ${ }^{82}$

8.

عن ميمونة زوج التبي صلى الله عليه وسلم قالت توضأ رسول الله صلى الله عليه وسلم وضوءه للصلاة غير رجليه وغسل فرجه وما أصابه من الأذى ثم أفاض عليه الماء ثم نحى رجليه فغسلهما هذه غسله من الجنابة

\footnotetext{
78 Şârihlerin iktibasta bulunduğu, Ebû Nuaym'ın Buhârînin Sahîh'i üzerine yazdığı müstahrec olduğu anlaşılan bu eser kayıp kitaplardan olup henüz ortaya çıkarılamamıştır.

79 İbn Hacer, Fethu'l-bârî, I, 776. Kirmânî de bu râvîyi Muhammed b. Yusuf el-Firyâbî olarak kaydetmiştir. Bkz. Kirmânî, el-Kevâkibu'd-derârî, III, 100.

80 Buhârî, Vudû 75, no: 247.

81 İbn Hacer, Fethu'l-bârî, I, 780; Aynî, Umdetü'l-kârî, III, 278.

82 Kirmânî, el-Kevâkibu'd-derârî, III, 106. Aynî'nin, isim vermeden bu kısmı olduğu gibi Kirmânî'den naklettiği anlaşılmaktadır. Bkz. Aynî, Umdetü'l-kârî, III, 278.
} 
Hz. Peygamber'in (a.s.) eşi Meymûne'den nakledildiğine göre o şöyle demiştir: "Rasûlullah (a.s.) ayaklarını yıkama dışında namaz için abdest aldığı gibi abdest aldı. Tenâsül uzvunu ve ona isabet eden necaseti yıkadı. Sonra kendi üzerine su döktü. Sonra da ayaklarını yerden çekip yıkadı. Iş̧te onun cünüblük nedeniyle guslü böyledir."83

Rivayetin, "Muhammed b. Yusuf- Süfyân- el-A'meş- Sâlim b. Ebu'l-Ca'dKüreyb- Íbn Abbâs- Meymûne." şeklindeki isnâdında yer alan Süfyân'ın Süfyân es-Sevrî olduğu İbn Hacer ve Aynî tarafından belirtilmiştir. ${ }^{84}$ Aynî bu görüşü isimlerini zikretmediği bir grup şârihe ve bazı âlimlere de nispet eder. Ancak bundan farklı olarak Kirmânî söz konusu râvînin Süfyân b. Uyeyne olduğu görüşündedir. Ona göre Buhârî'nin şeyhi de Muhammed b. Yusuf elBîkendî'dir. ${ }^{85} \mathrm{Ne}$ var ki Aynî’nin de işaret ettiği üzere Kirmânî bu sonuca iki farklı isnâdı ayırt edemeyip karıştırması sonucunda varmıştır. ${ }^{86}$ Buna göre Buhârî bu hadisi yukarıda kaydedilen isnâddaki şeyhi olan Muhammed b. Yusuf'un dışındaki iki şeyhinden olmak üzere ve farklı lafızlarla ve ziyadelerle "AbdânAbdullah b. el-Mübârek- Süfyân."87 ve "el-Humeydî- Süfyân."88 şeklindeki isnâdlarla da rivayet etmiştir. Bu isnâdlardan ilkinde de Süfyân, yukarıda kaydedilende olduğu gibi Süfyân es-Sevrî olup el-Humeydî'nin bulunduğu son isnâddaki Süfyân ise Süfyân b. Uyeyne'dir. Kirmânî'nin temyiz edemediği iki isnâd bu son kaydedilen isnâd ile Muhammed b. Yusuf'tan gelen isnâddır. İbn Hacer'in, Kirmânî'nin bu kanaate nasıl vardığını anlayamadığını belirtmesi de 89 Aynî'nin bu açıklaması ile uyumlu görünmektedir. Bu açıdan da mevzu bahis olan hadisin isnâdındaki râvînin Süfyân es-Sevrî olduğunun netlik kazandığı söylenebilir.

9.

حدثا عبد الله بن شداد قال سمعت ميمونة تقول كان رسول الله صلى الله عليه وسلم إذا أراد أن يباثر

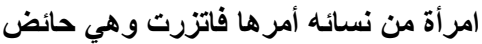

Abdullah b. Şeddâd, Meymûne'nin, "Rasûlullah (a.s.) eşlerinden biri ile hayızı iken mübâşerette bulunmak istediğinde hanımına emreder, o da

\footnotetext{
${ }^{83}$ Buhârî, Gusül 1, no: 249.

84 İbn Hacer, Fethu'l-bârî, I, 783; Aynî, Umdetül-kârî, III, 286.

${ }^{85}$ Kirmânî, el-Kevâkibu'd-derârî, III, 112. Ayrıca bkz. İbn Hacer, Fethu'l-bârî, I, 783; Aynî, Umdetü'lkârî, III, 286.

${ }^{86}$ Aynî, Umdetü'l-kârî, III, 286.

${ }^{87}$ Buhârî, Gusül 21, no: 281.

${ }^{88}$ Buhârî, Gusül 8, no: 260.

89 İbn Hacer, Fethu'l-bârî, I, 783.
} 
peştemal/izar (ile göbekle diz kapağı arasını) örterdi." dediğini işittiğini söylemiştir. ${ }^{90}$

Buhârî mezkûr rivayeti, içerisinde Süfyân bulunmayan bir isnâd ${ }^{91}$ ile naklettikten sonra Süfyân'ın da isnâddaki râvîlerden (Ebû İshâk) eşŞeybânî'den rivayet ettiğini belirtmiştir (ورواه سفيان عن الثيباني). Aynî, bazı âlimlerin bu Süfyân'ın Süfyân es-Sevrî olduğunu söylediklerini bildirmektedir ki² İbn Hacer onlardan biridir. ${ }^{93}$ Kirmânî ise konuyla ilgili temel ilkeye uygun olarak bunun es-Sevrî veya İbn Uyeyne olması arasında fark bulunmadığını, her ikisinin de Buhârî'nin sıhhat şartlarına uygun olduğunu ve mübhem bırakılmalarında bir sorun olmadığını ifade etmiştir. ${ }^{94}$

10.

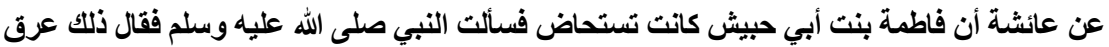

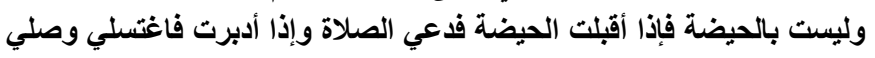

Hz. Âişe'den nakledildiğine göre o şöyle demiştir: "Fâtıma binti Ebû Hubeyş istihâza olmaktaydı. Bu durumu Hz. Peygamber'e (a.s.) sordu. Hz. Peygamber (a.s.), 'Bu bir damardır. Hayız değildir. Hayız zamanın geldiğinde namazı bırak. Hayzın müddeti geçtiği zaman da yıkan ve namaz kıl.' buyurdu."95

Rivayetin, "Abdullah b. Muhammed (el-Müsnedî)- Süfyân- HişâmBabası (Urve)- Âişe.” şeklindeki isnâdında yer alan Süfyân'ın Süfyân b. Uyeyne olduğu Kirmânî, İbn Hacer ve Aynî tarafından belirtilmiş ve son iki şârih bu tespitin gerekçesi olarak da isnâddaki diğer râvî Abdullah b. Muhammed elMüsnedî̀nin Süfyân es-Sevrî'den hadis işitmemiş olmasına dikkat çekmişlerdir. ${ }^{96}$

11.

عن سهل بن سعد قال كان رجال يصلون مع النبي صلى الله عليه وسلم عاقدي أزرهم على أعناقهم

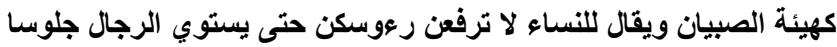

Sehl b. Sa'd'dan nakledildiğine göre o, "Bazı erkekler, bellerindeki futaları (dar oldukları için) çocuklar gibi boyunlarına bağlamış olarak $\mathrm{Hz}$.

\footnotetext{
${ }^{90}$ Buhârî, Hayz 5, no: 303.

91 İsnâd şöyledir: "Ebu'n-Nu'mân- Abdülvâhid- eş-Şeybânî- Abdullah b. Şeddâd-Meymûne."

${ }_{92}^{2}$ Aynî, Umdetü'l-kârî, III, 399.

93 İbn Hacer, Fethu'l-bârî, I, 819.

${ }^{94}$ Kirmânî, el-Kevâkibu'd-derârî, III, 168. Ayrıca bkz. Aynî, Umdetü'l-kârî, III, 399.

${ }^{95}$ Buhârî, Hayz 19, no: 320.

96 Kirmânî, el-Kevâkibu'd-derârî, III, 191; İbn Hacer, Fethu'l-bârî, I, 832; Aynî, Umdetü'l-kârî, III, 443-444.
} 
Peygamberle (a.s.) birlikte namaz kılarlardı. Bu sırada kadınlara da 'Erkekler doğrulup oturmadıkça başlarınızı secdeden kaldırmayın!' denirdi." demiştir. ${ }^{97}$

Rivayetin, "Müsedded- Yahya- Süfyân- Ebû Hâzim- Sehl." şeklindeki isnâdında yer alan Süfyân da İbn Hacer ve Aynî'nin belirttiklerine göre Süfyân es-Sevrî'dir. ${ }^{98}$ Ayrıca Mizzî de Tuhfetü'l-eşrâf'da bu râvîyi Süfyân b. Saîd b. Mesrûk es-Sevrî olarak tam ismiyle tayin etmiştir. ${ }^{99}$ Ancak Kirmânî bu râvînin Süfyân es-Sevrî olduğunu ifade ettikten sonra Süfyân b. Uyeyne olmasının da muhtemel olduğunu, çünkü iki Süfyân'ın da Ebû Hâzim'den rivayette bulunduğunu belirtmiştir. 100

12.

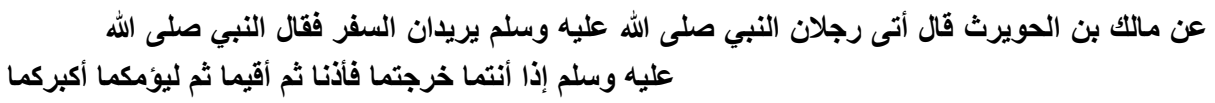

Mâlik b. el-Huveyris'den nakledildiğine göre yolculuğa çıkmak isteyen iki kişi Hz. Peygamber'e (a.s.) geldiğinde Hz. Peygamber (a.s.) onlara, "Yola çıktığınızda namaz vakti geldiği zaman ezan okuyun sonra kâmet getirin, sonra da en büyüğünüz size imamlık yapsın!" dedi. ${ }^{101}$

Rivayetin, "Muhammed b. Yusuf- Süfyân- Hâlid el-Hazzâ- Ebû KılâbeMâlik b. el-Huveyris." şeklindeki isnâdında yer alan Süfyân'ın Süfyân es-Sevrî olduğunu belirten Aynî, muhtemel bir soruya da yer vermektedir. Buna göre Buhârî̀nin, "Muhammed b. Yusuf- Süfyân b. Uyeyne." isnâdı ile de rivayet etmesi nedeniyle buradaki râvînin Süfyân es-Sevrî olduğu nereden bilinecektir? Aynî bu soruya, İbn Uyeyne'den rivayet eden râvînin Muhammed b. Yusuf elBikendî olduğu ve bunun es-Sevrî'den rivayetinin bulunmadığını söyleyerek cevap verir. Aynî'nin intimal dâhilinde gördüğü bir soru da bu rivayetin isnâdındaki râvî Muhammed b. Yusuf el-Firyâbî'nin İbn Uyeyne'den de rivayet etmiş olması nedeniyle bu ayrımın nasıl yapılacağı yönündedir. Aynînnin buna cevabı ise el-Firyâbî'nin mutlak olarak Süfyân dediğinde bununla es-Sevrî’yi kastettiği, İbn Uyeyne'den rivayet ettiğinde ise onun ismini tasrih ettiği şeklindedir. ${ }^{102}$ Söz konusu râvîlerle ilgili olarak İbn Hacer'in verdiği bilgiler de aynı yönde olup ayrıca o, Buhârî'nin şeyhinin Muhammed b. Yusuf el-Firyâbî olduğunu Ebû Nuaym'ın el-Müstahrec'inde tasrih ettiğine de işaret etmiştir. ${ }^{103}$

\footnotetext{
${ }^{97}$ Buhârî, Salât 6, no: 362.

98 İbn Hacer, Fethu'l-bârî, II, 39; Aynî, Umdetü'l-kârî, IV, 102.

${ }^{99}$ Mizzî, Tuhfetü'l-eşrâf, IV, 105, no: 4681. Ayrıca bkz. Aynî, Umdetü'l-kârî, IV, 102.

100 Kirmânî, el-Kevâkibu'd-derârî, IV, 21. Ayrıca bkz. Aynî, Umdetü'l-kârî, IV, 102.

${ }^{101}$ Buhârî, Ezân 18, no: 630.

102 Aynî, Umdetü'l-kârî, V, 212.

103 İbn Hacer, Fethu'l-bârî, II, 228.
} 
13.

عن أبي مسعود قال قال رجل يا رسول الله إني لأتأخر عن الصلاة في الفجر مما يطيل بنا فلان فيها

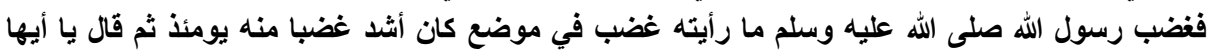

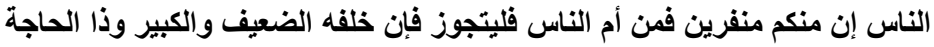

Ebû Mesûd'dan nakledildiğine göre bir adam Hz. Peygamber'e (a.s.), "Yâ Rasûlallah! Falan kişinin uzun kıldırması nedeniyle sabah namazında cemaate katılamıyorum." dedi. Bunun üzerine Rasûlullah (a.s.) öfkelendi. Öyle ki bir yerde o günkünden daha çok öfkelendiğini görmedim. Hz. Peygamber (a.s.) sonra, 'Ey insanlar! lç̧inizde nefret ettirenler var. Her kim cemaate imamlık yapacak olursa namazı hafif tutsun. Muhakkak ki onun arkasında zayıf, yaşlı ve ihtiyaç sahibi kimseler vardır." buyurdu. ${ }^{104}$

Rivayetin, "Muhammed b. Yusuf- Süfyân- İsmail b. Ebû Hâlid-Kays b. Ebû Hâzim- Ebû Mesûd." şeklindeki isnâdında Buhârînnin şeyhi olarak bulunan râvî, Aynî'nin tespitine göre Muhammed b. Yusuf el-Firyâbî, Süfyân ise Süfyân es-Sevrî'dir. Ancak burada Buhârî'nin şeyhinin Muhammed b. Yusuf el-Bîkendî, Süfyân'ın ise Süfyân b. Uyeyne olduğu da söylenmiştir. Bununla beraber Aynî önceki görüşün daha sahîh olduğunu ve Ebû Nuaym'ın tespitinin de bu yönde olduğunu belirtmiştir. ${ }^{105}$

14.

عن الأسود قال سمعت جندبا يقول اشتكى النبي صلى الله عليه وسلم فلم يقم ليلة أو ليلتين

Esved'den nakledildiğine göre o, Cündeb'in, "Hz. Peygamber'in (a.s.) ağrıları şiddetlendi. Bir veya iki gece (teheccüd namazına) kalkmadı." dediğini işittiğini söylemiştir. ${ }^{106}$

15.

عن جندب بن عبد الله رضي الله عذه قال احتبس جبريل صلى الله عليه وسلم على النبي صلى الله عليه

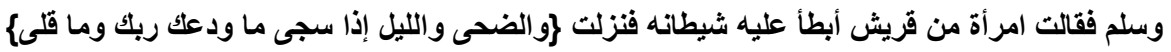

Cündeb b. Abdullah'dan rivayet edildiğine göre o, Cibrîl'in $\mathrm{Hz}$. Peygamber'e (a.s.) gelişinin bir süre kesilmesi üzerine Kureyş'ten bir kadının, "Şeytanı ona gelmekte gecikti." dediğini bunun üzerine de, "Kuş/uk vaktine ve karanlığı çöktüğü zaman geceye andolsun ki rabbin seni terk etmedi ve sana darılmadı da." (Duhâ, 93/1-3) âyetlerinin indiğini söyledi. ${ }^{107}$

\footnotetext{
${ }^{104}$ Buhârî, Ezân 63, no: 704.

${ }^{105}$ Aynî, Umdetü'l-kârî, V, 354-355.

106 Buhârî, Teheccüd 4, no: 1124.

107 Buhârî, Teheccüd 4, no: 1125.
} 
Kaydedilen bu iki rivayetin, "Ebû Nuaym- Süfyân- el-Esved-Cündeb." ve "Muhammed b. Kesîr- Süfyân- el-Esved b. Kays- Cündeb b. Abdullah." şeklindeki isnâdlarında yer alan Süfyân da İbn Hacer'in ve Aynî'nin belirttiklerine göre Süfyân es-Sevrî'dir. ${ }^{108}$ Bu râvî Tuhfetü'l-eşrâfda Mizzî tarafından da Süfyân es-Sevrî olarak tayin edilmiştir. ${ }^{109}$ İbn Hacer ayrıca bunun Süfyân b. Uyeyne olduğunu zannedenlerin yanıldıklarını da söylemiştir. ${ }^{110}$

16.

عبد الله بن شداد قال سمعت عليا رضي الله عنه يقول ما رأيت النبي صلى الله عليه وسلم يفدي رجلا بعد سعد سمعته يقول ارم فدالك أبي وأمي

Abdullah b. Şeddâd'dan nakledildiğine göre o, Hz. Ali'nin şöyle dediğini haber vermiştir: "Hz. Peygamber'in (a.s.) babasını ve annesini Sa'd'den (İbn Ebû Vakkâs) başka bir kimseye feda ederek seslendiğini görmedim. Rasûlullah (Uhud gününde ok atmasını isterken ona), 'At! Babam ve annem sana feda olsun!' diyordu."111

Rivayetin, "Müsedded- Yahya- Süfyân- Sa'd b. Ibrahim- Abdullah b. Şeddâd- Ali." ve "Kabîsa- Süfyân- Sa'd b. İbrahim- Abdullah b. Şeddâd- Ali." şeklindeki isnâdlarında yer alan Süfyân'ın Süfyân es-Sevrî olduğu İbn Hacer ve Aynî tarafından belirtilmiştir. ${ }^{112}$ Bu iki müellif Ebû Nuaym'ın, el-Müstahrec'inde kaydettiği bir görüşünden de bahsetmişlerdir. Buna göre Ebû Nuaym "Kabîsa" lafzının Buhârî’nin dışındaki râvîler tarafından tashîf edilerek nakledildiğini, doğrusunun ise "Kuteybe" olduğunu iddia etmiştir. Kuteybe'nin Süfyân esSevrî'den hadis işitmemiş olması nedeniyle de ona göre bu râvînin Süfyân b. Uyeyne olması gerekir. Fakat onun bu itirazının anlamlı olmadığı belirtilmiştir. Çünkü rivayetin her iki Süfyân'dan da nakledilmiş olmasının önünde bir engel bulunmamaktadır. ${ }^{113}$

17.

عن سعيد بن زيد رضي الله عنه قال قال رسول الله صلى الله عليه وسلم الكمأة من المن وماؤها شفاء للعين

Saîd b. Zeyd'den nakledildiğine göre o, Hz. Peygamber'in (a.s.), "Beyaz yer mantarı, kudret helvası türündendir. Suyu da göz (hastalıkları) için şifâdır." dediğini söylemiştir. ${ }^{114}$

\footnotetext{
108 İbn Hacer, Fethu'l-bârî, II, 617. Aynî, Umdetü'l-kârî, VII, 248, 251.

${ }^{109}$ Mizzî, Tuhfetü'l-eşrâf, II, 439, no: 3249. Ayrıca bkz. Aynî, Umdetü’l-kârî, VII, 248.

110 İbn Hacer, Fethu'l-bârî, II, 617.

${ }^{111}$ Buhârî, Cihâd 80, no: 2905.

112 İbn Hacer, Fethu'l-bârî, IV, 300; Aynî, Umdetü'l-kârî, XIV, 260.

113 İbn Hacer, Fethu'l-bârî, IV, 300; Aynî, Umdetü'l-kârî, XIV, 260.

${ }^{114}$ Buhârî, Tefsîr 2, no: 4478.
} 
Rivayetin, "Ebû Nuaym- Süfyân- Abdülmelik- Amr b. Hureys- Saîd b. Zeyd." şeklindeki isnâdında yer alan Süfyân da Aynî'nin ifadesine göre, her ne kadar Abdülmelik b. Umeyr'den Süfyân b. Uyeyne de rivayet etmiş olsa da Süfyân es-Sevrî'dir. Çünkü isnâd mutlak olarak Süfyân'ın Abdülmelik'den nakli suretinde olursa bu râvî çoğunlukla Süfyân es-Sevrî olur. Ebû Mesûd da bu hadisi zikrettiği zaman böyle söylemiştir. ${ }^{115}$ Kirmânî'nin görüşü de bu yöndedir. ${ }^{116}$

18.

عن ابن المنكدر سمعت جابرا رضي الله عنه قال كانت اليهود تقول إذا جامعها من ورائها جاء الولا

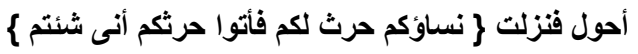

İbnü'l-Münkedir'in Câbir'den naklettiğine göre o şöyle demiştir: "Yahudiler, eşleri ile arkadan cinsî münasebette bulunduklarında doğacak çocuğun şaşı olacağını söylemekteydiler. Bunun üzerine, 'Kadınlarınız sizin tarlanızdır, tarlanıza istediğiniz gibi varın!' (Bakara, 2/223) âyeti indi."117

Rivayetin, "Ebû Nuaym- Süfyân- Ibnül-Münkedir- Câbir." şeklindeki isnâdında yer alan Süfyân'ın Süfyân es-Sevrî olduğunu Aynî'nin belirttiğine göre bazı âlimler söylemişlerdir ki ${ }^{118}$ İbn Hacer onlardan biridir. ${ }^{119}$ Ancak buna muhalif olarak Mizzî Tuhfetü'l-eşrâfda bu râvînin ismini Süfyân b. Uyeyne b. Ebû İmrân el-Hilâlî şeklinde, künyesi ve nisbesi ile birlikte tespit etmiştir. ${ }^{120}$

19.

$$
\text { عن عائشة رضي الله عنها \} والذي تولى كبره \{ قالت عبد الله بن أبي ابن سلول }
$$

Hz. Âişe'den nakledildiğine göre o, ifk olayı hakkındaki, “Onun büyüğünü üzerine alan (ve iftirayı başlatan...)" âyetinde bahsedilen kişinin Abdullah b. Ubey b. Selûl olduğunu söylemiştir."121

Rivayetin, "Ebû Nuaym- Süfyân-Ma'mer- Zührî- Urve- Âişe." şeklindeki isnâdında yer alan Süfyân da, İbn Hacer ve Aynînin ifadesiyle Süfyân esSevrî'dir. Nitekim İbn Merdûye Buhârî'nin şeyhi Ebû Nuaym'dan bir başka isnâd ile bunu tasrih etmiştir. ${ }^{122}$

\footnotetext{
${ }^{115}$ Aynî, Umdetü'l-kârî, XVIII, 115.

116 Kirmânî, el-Kevâkibu'd-derârî, XVII, 7.

117 Buhârî, Tefsîr 2, no: 4528.

${ }^{118}$ Aynî, Umdetü'l-kârî, XVIII, 156.

119 İbn Hacer, Fethu'l-bârî, V, 498.

120 Mizzî, Tuhfetü'l-eşrâf, II, 362, 363. Ayrıca bkz. Aynî, Umdetü'l-kârî, XVIII, 156.

${ }^{121}$ Buhârî, Tefsîr 24, no: 4749.

122 İbn Hacer, Fethu'l-bârî, V, 718; Aynî, Umdetül-kârî, XIX, 114. Bu iktibas muhtemelen İbn Merdûye'nin, Buhârî̀nin el-Câmiu's-sahîh'i üzerine yazdığı el-Müstahrec alâ Sahîhi'l-Buhârî isimli eserinden yapılmış olmakla beraber bu eserin zamanımıza ulaşıp ulaşmadığı, matbu olup olmadığı belirlenememiştir.
} 
20.

عن ابن مسعود قال انثق القمر على عهل رسول الله صلى الله عليه وسلم فرقتين فرقة فوق الجبل

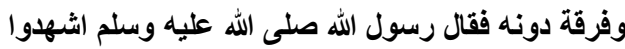

İbn Mesûd'dan nakledildiğine göre o şöyle demiştir: "Rasûlullah zamanında ay iki parçaya ayrılmış, bir parçası dağın üstünde bir parçası da önünde kalmıştı. Bunun üzerine Rasûlullah, 'Şâhid olun!' buyurdu."123

Rivayetin, “Müsedded- Yahya- Şu'be ve Süfyân- el-A'meş- Ibrahim- Ebû Ma'mer- İbn Mesûd." şeklindeki isnâdında yer alan Süfyân, Aynînnin belirttiğine göre İbn Uyeyne de es-Sevrî de olabilir. Çünkü her ikisi de Süleyman elA'meş'den rivayet etmiştir. ${ }^{124}$

21.

عن زيد بن أسلم قال سمعت ابن عمر يقول جاء رجلان من المشرق فخطبا فقال النبي صلى الله عليه وسلم إن من البيان لسحرا

Zeyd b. Eslem'den nakledildiğine göre o, İbn Ömer'in şöyle dediğini işittiğini söylemiştir: "(Medine'nin) doğu tarafından iki adam gelip hitapta bulundular. Bunun üzerine Hz. Peygamber (a.s.), 'Şüphesiz beyânın bir kısmı sihirdir (bazı sözler büyüleyicidir).' dedi."125

Rivayetin, "Kabîsa- Süfyân- Zeyd b. Eslem- Ibn Ömer." şeklindeki isnâdında yer alan Süfyân da Aynî'nin belirttiğine göre Süfyân es-Sevrî'dir. ${ }^{126}$ Ancak Kirmânî Nevevî'den naklen rivayetin Süfyân b. Uyeyne'den de nakledildiğini belirtmiştir. Bununla beraber o, her iki râvînin Buhârî'nin sıhhat şartlarına uygun olmaları nedeniyle isnâdın sıhhatine zarar gelmediğini de söylemiştir. ${ }^{127}$

22.

عن جابر بن عبد الله رضي الله عنهما قال قال رسول الله صلى الله عليه وسلم هل اتخذتم أنماطا قلت يا رسول الله وأنى لنا أنماط قال إنها أنها ستكون

Câbir b. Abdullah'dan nakledildiğine göre (evlendiği sırada) Rasûlullah (a.s.) ona, "Etrafı saçaklı döşek yüzleri edindiniz mi?" diye sordu. O da, "Yâ Rasûlallah! Bizim böyle döşek yüzlerimiz nereden olacak?" dedi. Rasûlullah (a.s.) cevaben, "Muhakkak ki gelecekte (bunlar) olacak." buyurdu. ${ }^{128}$

\footnotetext{
${ }^{123}$ Buhârî, Tefsîr 54, no: 4864.

${ }^{124}$ Aynî, Umdetü'l-kârî, XIX, 297.

125 Buhârî, Nikâh 48, no: 5146.

${ }^{126}$ Aynî, Umdetü'l-kârî, XX, 189.

127 Kirmânî, el-Kevâkibu'd-derârî, XIX, 108. Ayrıca bkz. Aynî, Umdetü'l-kârî, XX, 189

${ }^{128}$ Buhârî, Nikâh 63, no: 5161.
} 
Rivayetin, "Kuteybe b. Saîd- Süfyân-Muhammed b. el-Münkedir- Câbir b. Abdullah." şeklindeki isnâdında yer alan Süfyân da Aynî'nin belirttiğine göre İbn Uyeyne'dir. ${ }^{129}$ Aynı rivayetin yine Buhârî tarafından tahric edilen kısmen farklı lafızlara ve ziyadelere sahip farklı bir metninin isnâdında da Süfyân'ın Muhammed b. el-Münkedir'den nakli söz konusudur. ${ }^{130}$ Ancak buradaki Süfyân'ın es-Sevrî olduğunu Aynî özellikle belirtmiştir. ${ }^{131} \mathrm{Bu}$ durum bilhassa Aynî'nin râvîlerin kimliğini belirleme konusundaki hassasiyetini ve mevzumuz olan râvîlerin kim olduğunun belirlenmesinin imkân dâhilinde olduğunu göstermesi açısından önemlidir. Diğer taraftan Buhârî'nin bu rivayetteki şeyhi de öncekinden farklı olup Amr b. Abbâs'dır. Bu râvî de rivayeti İbn Mehdî'den almakla Buhârî ile Süfyân es-Sevrî arasındaki râvî iki olmuş olur. Öncekinde ise yukarıda da kaydedildiği üzere Kuteybe b. Saîd'dir ki Buhârî ile Süfyân b. Uyeyne arasında mezkûr isnâda göre sadece bu râvî bulunmaktadır.

23.

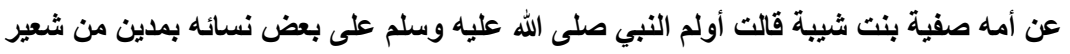

Safiyye binti Şeybe'den nakledildiğine göre o, "Hz. Peygamber (a.s.), eşlerinden bazılarıyla evlenirken iki müdd arpa unuyla düğün yemeği verdi." demiştir. ${ }^{132}$

Rivayetin, "Muhammed b. Yusuf- Süfyân- Mansûr b. Safiyye- Annesi Safiyye binti Şeybe." şeklindeki isnâdında yer alan Süfyân, İbn Hacer ve Aynî'nin belirttiklerine göre Süfyân es-Sevrî'dir. ${ }^{133}$ İbn Hacer mezkûr isnâdın, "el-Firyâbî- es-Sevrî." şeklinde olduğunun kendisi açısından kesin olduğunu134 belirtmekle beraber Kirmânî bir başka intimale daha işaret etmiştir. Buna göre Buhârî̀nin şeyhi Muhammed b. Yusuf el-Firyâbî değil Muhammed b. Yusuf elBikendî olup hadisi bunun aldığı kişi de Süfyân b. Uyeyne'dir. ${ }^{135}$ Çünkü her iki Muhammed de her iki Süfyân'dan rivayette bulunmuştur. Ancak yine Kirmânî'nin kaydettiğine göre bu belirsizlik, her iki râvînin de Buhârî'nin şartlarına uygun olması nedeniyle isnâdı zayıflatmaz. ${ }^{136}$

24.

\footnotetext{
${ }^{129}$ Aynî, Umdetü'l-kârî, XX, 210.

${ }^{130}$ Buhârî, Menâkıb 25, no: 3631.

131 Aynî, Umdetü'l-kârî, XX, 210.

132 Buhârî, Nikâh 71, no: 5172.

133 İbn Hacer, Fethu'l-bârî, VI, 341; Aynî, Umdetü'l-kârî, XX, 220.

134 İbn Hacer, Fethu'l-bârî, VI, 341. Rivayetin yine Süfyân es-Sevrî'den nakledilen diğer bazı isnâdları için bkz. İbn Hacer, Fethu'l-bârî, VI, 341.

135 İsmâilî ve Ebû Nuaym Mustahrec'lerinde bu râvînin Muhammed b. Yusuf el-Firyâbî olduğunu kesin olarak belirtmişlerdir. Bkz. İbn Hacer, Fethu'l-bârî, VI, 341; Aynî, Umdetü'l-kârî, XX, 220.

${ }^{136}$ Kirmânî, el-Kevâkibu'd-derârî, XIX, 123; İbn Hacer, Fethu'I-bârî, VI, 341; Aynî, Umdetü'l-kârî, $\mathrm{XX}, 220$.
} 


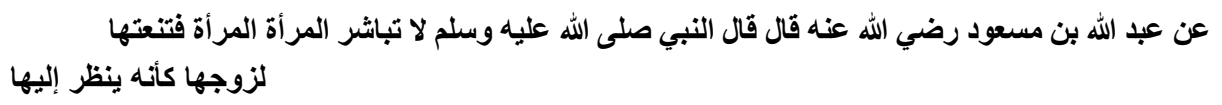

Abdullah b. Mesûd'dan nakledildiğine göre o, Hz. Peygamber'in (a.s.), "Kadın kadına temas etmesin! Sonra onlardan biri kocasına diğer kadının vasıflarını öyle anlatır ki sanki kocası onu görüyormuş gibi olur." buyurduğunu söylemiştir. ${ }^{137}$

Rivayetin, "Muhammed b. Yusuf- Süfyân-Mansûr- Ebû Vâil- Abdullah b. Mesûd." şeklindeki isnâdında yer alan Süfyân, Aynî'nin belirttiğine göre İbn Uyeyne, Buhârî'nin şeyhi olan Muhammed b. Yusuf da el-Bikendî'dir. Ancak bu isnâda dair farklı bir görüş daha bulunmaktadır ki Süfyân'ın es-Sevrî, Muhammed b. Yusuf'un da el-Firyâbî olduğu yönündedir. Ne var ki bu görüşün tashihe intiyacı olduğu belirtilmiştir. ${ }^{138}$

\section{5.}

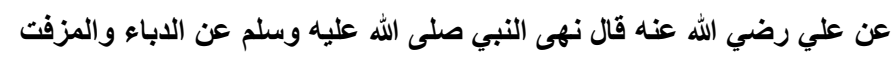

Hz. Ali'den nakledildiğine göre o şöyle demiştir: "Hz. Peygamber dubbâ ve müzeffet olarak isimlendirilen kaplarda (şıra yapmayı) yasakladı."139

Rivayetin, "Müsedded- Yahya- Süfyân- Süleyman- Ibrahim et-Teymî- elHâris b. Süveyd-Ali." şeklindeki isnâdında yer alan Süfyân'ın da es-Sevrî veya İbn Uyeyne olması Aynî̀nin belirttiğine göre intimal dâhilindedir. Çünkü Yahya el-Kattân her iki Süfyân'dan da rivayet ettiği gibi bunların her ikisi de Süleyman el-A'meş'den rivayet etmişlerdir. ${ }^{140}$

26.

عن ابن عباس قال شرب النبي صلى الله عليه وسلم قائما من زمزم

İbn Abbâs'dan nakledildiğine göre o şöyle demiştir: “Hz. Peygamber (a.s.) zemzem suyundan ayakta iken içti."141

Rivayetin, "Ebû Nuaym- Süfyân- Âsım el-Ahvel- eş-Şa'bî- İbn Abbâs." şeklindeki isnâdında yer alan Süfyân'ın kimliği de ihtilaflıdır. Kirmânî bu konuda Kelâbâzî'nin bir görüşünü nakletmektedir. Buna göre Ebû Nuaym'ın, hem Süfyân es-Sevrî'den hem de Süfyân b. Uyeyne'den hadis işitmiş olması ve bu ikisinin de Âsım el-Ahvel'den semâlarının bulunması nedeniyle bu Süfyân'ın

\footnotetext{
${ }^{137}$ Buhârî, Nikâh 119, no: 5240.

${ }^{138}$ Aynî, Umdetü'l-kârî, XX, 311.

${ }^{139}$ Buhârî, Eşribe 8, no: 5594.

${ }^{140}$ Aynî, Umdetü'l-kârî, XXI, 267.

${ }^{141}$ Buhârî, Eşribe 16, no: 5617.
} 
her ikisinden biri olma intimali vardır. ${ }^{142}$ Fakat İbn Hacer bu görüşe karşı çıkarak iki muhaddis arasındaki söz konusu intimalin eşit düzeyde olmadığını söylemiştir. Çünkü Ebû Nuaym Süfyân es-Sevrî'den rivayet etmekle meşhurdur ve ondan ayrılmaması ile bilinmektedir. İbn Uyeyne'den rivayeti ise azdır. Şeyhinin ismini mutlak olarak zikredip tayin etmediğinde bu şeyhinin, kendisiyle sohbet ve arkadaşlığı bilinen ve yine kendisinden çokça rivayet ettiği şeyhi olduğu kabul edilir. Mizzî'nin Tuhfetü'l-eşrâf da ${ }^{143}$ bu râvînin Süfyân es-Sevrî olduğunu kesin olarak bildirmesinin temelinde de, bu gibi durumlarda muhaddislerin sürekli başvurduğu bu ilke vardır. ${ }^{144}$ Aynî'nin ise bu son görüşe katılmadığı anlaşılmaktadır. Nitekim o, Ebû Nuaym'ın İbn Uyeyne'den rivayeti sabit olduktan sonra söz konusu intimalin her zaman mevcut olacağını ve yukarıda zikredilen gerekçelerle birini diğerine tercih etmenin mümkün olamayacağını belirtmiştir. Buna ek olarak Aynî hadisin aynısını, Müslim’in (ö. 261/875) Sahîh'inde ${ }^{145}$ ve Ahmed b. Hanbel'in Müsned'inde ${ }^{146}$ tahric edilmiş olmak üzere, Süfyân b. Uyeyne'nin de rivayet ettiğini söylemiştir. ${ }^{147}$ Rivayetin farklı kaynaklarda İbn Uyeyne'den de nakledildiğini gösteren bu bilgi İbn Hacer tarafından da kaydedilmekle beraber o, mevzu bahis olan rivayetin Süfyân esSevrî'den nakledildiğini özellikle vurgulamıştır. ${ }^{148}$ Ayrıca Ahmed b. Hanbel rivayeti Süfyân es-Sevrî'den de nakletmiştir ki ${ }^{149}$ buna İbn Hacer tarafından da dikkat çekilmiştir. ${ }^{150}$

27.

عن عبد الله بن عمرو عن النبي صلى الله عليه وسلم قال ليس الواصل بالمكافئ ولكن الواصل الذي إذا قطعت رحمه وصلها

Abdullah b. Amr'ın Hz. Peygamber'den (a.s.) naklettiğine göre o, "Karşılık vermek için yapan kişi gerçekten sıla-i rahim yapmış olmaz. Akrabaları kendisi ile bağlarını kestiği halde bu bağları koruyan kişi gerçekten sıla-i rahim yapmış olur." buyurmuştur. ${ }^{151}$

\footnotetext{
142 Kirmânî, el-Kevâkibu'd-derârî, XX, 162. Ayrıca bkz. İbn Hacer, Fethu'l-bârî, VI, 757; Aynî, Umdetü'l-kârî, XXI, 288.

${ }_{143}$ Mizzî, Tuhfetü'l-eşrâf, V, 33, no: 5767.

144 İbn Hacer, Fethu'l-bârî, VI, 757. Ayrıca bkz. Aynî, Umdetü'l-kârî, XXI, 288.

145 Müslim, Ebü'l-Huseyn Müslim b. Haccâc, el-Câmiu's-sahîh, I-III, Çağrı Yay. ve Dâru Sehnûn, İstanbul 1413/1992, Eşribe 118, no: 2027.

${ }^{146}$ Ahmed b. Hanbel, Ebû Abdullah eş-Şeybânî, Müsned, I-L, thk. Şuayb el-Arnaût ve diğerleri, Müessesetü'r-Risâle, Beyrut 1416/1995, III, 387-388, no: 1903.

${ }^{147}$ Aynî, Umdetü'l-kârî, XXI, 288.

148 İbn Hacer, Fethu'l-bârî, VI, 757.

${ }^{149}$ Ahmed, Müsned, V, 262, no: 3186. Bu isnâddaki râvînin Süfyân es-Sevrî olduğuna Şuayb elArnaût da işaret etmiştir.

150 ỉbn Hacer, Fethu'l-bârî, VI, 757.

151 Buhârî, Edeb 15, no: 5991.
} 
Rivayetin, "Muhammed b. Kesîr- Süfyân- el-A'meş, el-Hasen b. Amr, FItr- Mücâhid-Abdullah b. Amr." şeklindeki isnâdında yer alan Süfyân, İbn Hacer ve Aynî'nin tespitlerine göre Süfyân es-Sevrî'dir ki ${ }^{152}$ Ebû Dâvûd da (ö. 275/889) aynı isnâd ile hadisi tahric etmiştir. ${ }^{153}$ Tirmizî (ö. 279/892) ise bu hadisi el-Câmiu's-sahîh'deki, "Fıtr b. Halîfe- Mücâhid- Abdullah b. Amr." şeklindeki temel isnâd ve küçük bir lafız farkı ile Muhammed b. Yahya b. Ebû Ömer isimli şeyhi vasıtasıyla, ancak Süfyân b. Uyeyne'den rivayet etmiştir. Bu rivayette Süfyân'ın şeyhi de el-Câmiu's-sahîh'dekinden farklı olarak el-A'meş değil Beşîr Ebû İsmail'dir. ${ }^{154}$ Bu bilgiler ışığında rivayetin her iki Süfyân'dan da nakledilmiş olduğunu söylemek mümkündür.

28.

$$
\text { عن ابن عمر قال كاتت يمين النبي صلى الله عليه وسلم لا ومقلب القلوب }
$$

İbn Ömer'den nakledildiğine göre o Hz. Peygamber'in (a.s.) yemininin, "Hayır! Kalpleri evirip çeviren Allah'a yemin ederim!" şeklinde olduğunu söylemiştir. ${ }^{155}$

Rivayetin, "Muhammed b. Yusuf- Süfyân- Musa b. Ukbe- Sâlim- İbn Ömer.” şeklindeki isnâdında bulunan Süfyân'ın Süfyân es-Sevrî olduğu Aynî tarafından özellikle vurgulanmıştır. Buna göre Aynî hadisi Süfyân es-Sevrî'den nakleden râvînin Muhammed b. Yusuf el-Firyâbî olduğunu belirtmiş ve bu isnâdda kastedilenin Muhammed b. Yusuf el Bikendî'nin Süfyân b. Uyeyne'den nakli olmadığına dikkat çekerek bir yanlış anlaşılmaya mani olmak istemiştir. ${ }^{156}$ Söz konusu râvînin Süfyân es-Sevrî olduğuna İbn Hacer de işaret etmiş ayrıca Buhârî̀nin bu hadisi Muhammed b. Yusuf el-Bîkendî'nin Süfyân b. Uyeyne'den nakli suretinde de tahric ettiğini fakat bu rivayette kastedilenlerin bunlar olmadığını da belirtmiştir. ${ }^{157}$ Yine rivayeti Ebû Nuaym'ın, el-Mustahrec'inde, "Muhammed b. Yusuf el-Firyâbî- Süfyân es-Sevrî." isnâdı ile tahric ettiği, İsmailî̀nin (ö. 371/982) ve İbn Mâce'nin (ö. 273/886) ${ }^{158}$ Vekî, Nesâînin (ö.

\footnotetext{
152 İbn Hacer, Fethu'l-bârî, VII, 141; Aynî, Umdetü'l-kârî, XXII, 149.

153 Ebû Dâvûd, Süleyman b. el-Eş'as es-Sicistânî, Sünen, Dâru İbni'l-Cevzî, Kahire 1432/2011, Zekât 46, no: 1697. Rivayetin Süfyân es-Sevrî'den nakledilen merfû ve mevkûf bazı isnâdları için bkz. İbn Hacer, Fethu'l-bârî, VII, 141.

${ }^{154}$ Tirmizî, Ebû Îsâ Muhammed b. Îsâ b. Sevre, Câmiu't-Tirmizî, Dâru's-Selâm, Riyad 1999, Birr 10, no: 1908.

${ }^{155}$ Buhârî, Eymân 3, no: 6628.

156 Aynî, Umdetül-kârî, XXIII, 261.

157 İbn Hacer, Fethu'l-bârî, VII, 710.

158 Rivayet İbn Mace'nin Sünen'inde, كانت أكثر أيمان رسول الله صلى الله عليه و سلم لا ومصرف القلوب şeklindeki farklı lafızlarla ve İbn Hacer'in işaret ettiği isnâddan farklı bir isnâd ile nakledilmektedir. Bkz. İbn Mâce, Ebû Abdullah Muhammed b. Yezid el-Kazvînî, Sünenü İbn Mâce, I-II, Çağrı Yay. ve Dâru Sehnûn, İstanbul 1413/1992, Keffârât 1, no: 2092.
} 
303/915) ise Muhammed b. Bişr ${ }^{159}$ vasıtasıyla yine Süfyân es-Sevrî'den tahric ettikleri İbn Hacer tarafından kaydedilmiştir. ${ }^{160}$

29.

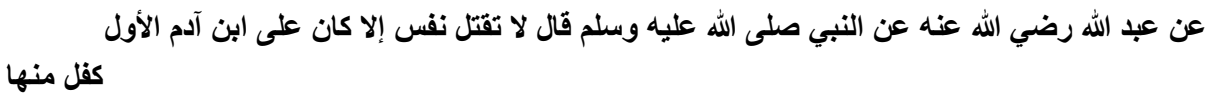

Abdullah (b. Mesûd)'un Hz. Peygamber'den (a.s.) naklettiğine göre o, "Bir insan öldürüldüğünde muhakkak ki bunun günâhı (bu suçu işleyen) ilk Âdemoğluna da yazılır." buyurmuştur. ${ }^{161}$

Rivayetin, "Kabîsa- Süfyân- el-A'meş- Abdullah b. Mürre- MesrûkAbdullah." şeklindeki isnâdında yer alan Süfyân, İbn Hacer'e göre Süfyân esSevrî'dir. Ancak İbn Hacer bunun Süfyân b. Uyeyne olma intimalinden de bahsetmiştir. ${ }^{162}$ Aynî'nin tespitine göre ise bu râvî Süfyân b. Uyeyne'dir. Aynî bunun Süfyân es-Sevrî olduğunun da söylenildiğini ifade etmekle beraber önceki görüşün daha açık olduğunu belirtmiştir. ${ }^{163}$

30.

عن عائشة رضي الله عنها قالت قلت يا رسول الله يستأمر النساء في أبضاعهن قال نعم قلت فإن البكر تستأمر فتستحيي فتسكت قال سكاتها إنهان فئها

Hz. Âişe'den nakledildiğine göre o Rasûlullah'a (a.s), kadınlarla nikâh akidleri hususunda istişare edilip edilmeyeceğini sordu. Rasûlullah (a.s) ona, "Evet (istişare edilir)." dedi. Hz. Âişe bunun üzerine, "Fakat bâkire kızla evleneceği kimse hakkında istişare edilirse utanır ve susar." dedi. Rasûlullah da, "Kızın susması onun iznidir." buyurdu. ${ }^{164}$

Rivayetin, "Muhammed b. Yusuf- Süfyân- İbn Cüreyc- İbn Ebû MüleykeEbû Amr (Zekvân)- Âişe." şeklindeki isnâdında yer alan Süfyân'ın kimliği, Aynî'nin kaydettiği üzere ihtilaflıdır. Buna göre Buhârî'nin şeyhi olan Muhammed b. Yusuf'un el-Firyâbî ve bunun şeyhinin de Süfyân es-Sevrî olması mümkün olduğu gibi Buhârî'nin şeyhi Muhammed b. Yusuf'un, Muhammed b. Yusuf el-Bîkendî ve onun şeyhinin Süfyân b. Uyeyne olması da mümkündür. Çünkü her iki Süfyân da Abdülmelik b. Abdülaziz b. Cüreyc'den rivayet etmekle meşhurdur. Fakat Ebû Nuaym bu hadisin kesin olarak el-

\footnotetext{
${ }^{159}$ Nesâî, Ebû Abdurrahman Ahmed b. Şuayb b. Ali el-Horâsânî, Sünenü'n-Nesâî, tsh. Ahmed Şemsüddin, Dâru'l-Kütübi'l-İlmiyye, Beyrut 2009, Eymân 1, no: 3766.

160 İbn Hacer, Fethu'l-bârî, VII, 710-711. İbn Hacer'in iktibasta bulunduğu tahmin edilen İsmâilî'nin el-Müstahrec isimli eserinin günümüze ulaşıp ulaşmadığı konusunda bir bilgi elde edilememiştir.

${ }^{161}$ Buhârî, Diyât 2, no: 6867 .

162 İbn Hacer, Fethu'l-bârî, VIII, 10

${ }^{163}$ Aynî, Umdetü'l-kârî, XXIV, 50.

${ }^{164}$ Buhârî, İkrâh 3, had. no: 6946.
} 
Firyâbî'den nakledildiğini belirtmiştir. el-Firyâbî ise mutlak olarak Süfyân'ı zikredip kimliğini tayin etmediğinde bu râvî Süfyân es-Sevrî'dir. Şayet Süfyân b. Uyeyne'yi murad ederse onu, kimliğini tayin ederek zikreder. ${ }^{165}$ İbn Hacer de yukarıda kaydedilen intimali zikretmekle beraber söz konusu râvînin Süfyân esSevrî olmasının açık olduğunu belirtmiştir. ${ }^{166}$ İbn Hacer'in bu kanaate ulaşmasında Ebû Nuaym'ın yukarıda kaydedilen görüşü ve el-Firyâbî'nin her iki Süfyân ile ilgili mezkûr yönteminin etkili olduğu anlaşılmaktadır. ${ }^{167}$

\section{SONUÇ}

Hadis musannefâtında, isnâdı oluşturan ricalin bazılarının, kendilerini tanımaya ve adaşlarından ayırt etmeye yarayacak lakap, nisbe ve künyeleri belirlenmeksizin zikredilmeleri anlamındaki "ihmâl" veya bu şekilde zikredilen râvî anlamındaki "mühmel" ile sıkça karşılaşılmaktadır. Araştırmada tespit edilen rivayetlerin isnâdları musannıfların bu yöndeki eğilimlerini somut olarak ortaya koymuştur. Anlaşıldığı kadarıyla bu uygulamanın normal sayılmasının temelinde, söz konusu eserlerin ilk olarak tasnif edildiği erken dönemlerde hadis ilminin en parlak devrini yaşıyor olması ile de ilgili olarak, isnâd sisteminin ciddi bir şekilde uygulanmaya devam edilmesi ve râvîler hakkındaki yüksek bilgi düzeyi gibi nedenlerle isimlerin tasrih edilmesinin bir ihtiyaç olarak belirmemesi bulunmaktadır. Fakat bahsedilen alanlarda sonraki yüz yıllarda meydana gelen gerileme bu vasıftaki isnâdları tartışmalı hale getirmiştir. Netice itibariyle konu hadis usûlü ilminin temel meselelerinden biri olmuş, bazı muhaddisler bu alanda uzmanlaşmış ve râvîlerin temyizini mümkün kılan eserler telif etmiş, ölçütler geliştirmişlerdir.

Bu araştırma söz konusu uygulamanın el-Câmiu's-sahîh'in metninde, Buhârî̀nin şeyhinin şeyhi konumundaki iki muhaddis, Süfyân b. Uyeyne ve Süfyân es-Sevrî hakkında da önemli düzeyde mevcut olduğunu göstermiştir.

Mezkûr iki râvînin hocalarının ve talebelerinin büyük oranda aynı olması ilk anda bunları temyiz etmenin mümkün olmadığı fikrini doğuruyorsa da detaylı inceleme bunların bazı râvîlerle özel birlikteliği olduğu ve dolayısıyla böyle bir temyizin imkân dâhilinde olduğunu göstermiştir. Nitekim seçilen örneklerin ortaya koyduğu üzere Muhammed b. Yusuf el-Firyâbî ile Süfyân es-Sevrî; Muhammed b. Yusuf el-Bîkendî ile de Süfyân b. Uyeyne arasında özel bir şeyhtalebe ilişkisi bulunduğu açıktır. Bu durum mühmel olarak zikredilen Süfyân'ın tayininin mümkün olmadığı tezinin en azından Buhârî'nin bu iki şeyhi

\footnotetext{
${ }^{165}$ Aynî, Umdetü'l-kârî, XXIV, 153-154; İbn Hacer, Fethu'l-bârî, VIII, 112.

166 İbn Hacer, Fethu'l-bârî, VIII, 112.

167 İbn Hacer, Fethu'l-bârî, VIII, 112.
}

ÇÜiFD, 2018, cilt: 18, sayı: 2, ss. 764-795. 
vasıtasıyla büyük oranda geçersiz kaldığını ortaya koymuştur. Yine mevzu bahis olan iki muhaddisin özel birliktelikleri bulunan râvîler sadece zikredilenler olmayıp başka bazı râvîlerin de bu niteliğe sahip bulunduğu el-Câmiu's-sahîh'in metni taranırken gözlemlenmiştir.

Diğer taraftan hemen hemen bütün isnâdlarda şârihler tarafından bu tayinin yapıldığının belirlenmiş olması da söz konusu iddianın temelinin olmadığını göstermiştir. Bu noktada Aynî'nin, Süfyân'ın kimliği ile ilgili herhangi bir açıklamada bulunmadığı 45 isnâd dışında yüzlerce isnâd içerisinden sadece 17 tanesini intilaflı olarak sunması ve tartışması da meselenin büyük oranda çözüldüğünü ve ciddi bir problem görünümünde olmadığını ortaya koymuştur.

Mevzu bahis olan uygulama râvîyi mechûl hale getirmesi ve neticede onun adalet ve zabt durumunu belirlemeye engel olması açısından genellikle isnâdı kusurlu hale getirirken, râvîler Süfyân b. Uyeyne ve Süfyân es-Sevrî gibi sika olduğu ittifakla kabul edilen kimseler olduğunda isnâdın sıhhati açısından herhangi bir sorun teşkil etmediği görülmüştür. Bununla beraber mutlaka bir tercih yapılması gerektiğinde daha kıdemli olması nedeniyle râvînin Süfyân esSevrî olarak tayin edilebileceği yönünde bir görüş de bulunmaktadır. Yine Süfyân b. Uyeyne hakkındaki, tedlis yaptığı veya ömrünün sonlarına doğru intilata uğradığı yönündeki bir takım zayıf iddialar da, şayet dikkate alınacak olursa bir tercih sebebi olarak görülebilir.

\section{Kaynakça}

Ahmed b. Hanbel, Ebû Abdullah eş-Şeybânî (ö. 241/855), Müsned, IL, thk. Şuayb el-Arnaût ve diğerleri, Müessesetü'r-Risâle, Beyrut 1416/1995.

Aydınlı, Abdullah, "Mühmel”, DIA, XXXI, s. 524, İstanbul 2006.

Aynî, Ebû Muhammed Bedruddin Mahmûd b. Ahmed b. Musa Hanefî (ö. 855/1451), Umdetü'l-kârî şerhu Sahîhi'l-Buhârî, I-XXV, tsh. Abdullah Mahmûd Muhammed Ömer, Dâru'I-Kütübi'I-İlmiyye, Beyrut, 1421/2001.

Buhârî, Muhammed b. İsmail (ö. 256/870), el-Camiu's-sahîh, Dâru'sSelâm, Riyad 1999.

Ebû Dâvûd, Süleyman b. el-Eş’as es-Sicistânî (ö. 275/889), Sünen, Dâru İbni'l-Cevzî, Kahire 1432/2011.

Hatîb el-Bağdâdî, Ebû Bekir Ahmed b. Ali b. Sâbit (ö. 463/1071), Kitâbu'I-kifâye fî ilmi'r-rivâye, Dâiretü'l-Maârifi'l-Osmaniyye, Haydarâbâd 1357. 
İbn Hacer, Şihâbeddin Ahmed b. Ali b. Muhammed b. Ahmed Askalânî (ö. 852/1449), Fethu'I-bârî şerhu Sahîhi'I-Buhârî, I-VIII, Dâru'I-Marife, Beyrut 2005.

Nüzhetü'n-nazar fî tavdîhi Nuhbeti'l-fiker fî mustalahi ehli'leser, thk. Nureddin Itr, Matbaatu's-Sabâh, Dımeşk 1421/2000.

Tehzîbu't-Tehzîb, I-IV, Müessesetü'r-Risâle, Beyrut 1995.

$1415 / 1995$.

.......... Takrîbu't-Tehzîb, I-II, Dâru'l-Kütübi'l-IImiyye, Beyrut

İbn Kesîr, Ebu'l-Fidâ el-Hâfız İmâdüddîn İsmail b. Ömer (ö. 774/1373), el-Bâisü'l-hasîs şerhu Ihtisâri ulûmi'l-hadîs, thk. Ahmed Muhammed Şâkir, Dâru'l-Fikr, Beyrut 1416/1996.

İbn Mâce, Ebû Abdullah Muhammed b. Yezid el-Kazvînî (ö. 273/886), Sünenü Ibn Mâce, I-II, Çağrı Yay. ve Dâru Sehnûn, İstanbul 1413/1992.

İbn Manzûr, Cemalüddin Muhammed b. Mükerrem (ö. 711/1311), Lisanu'l-Arab, I-VI, thk. Abdullah Ali el-Kebîr, Muhammed Ahmed Hasebullah, Hâşim Muhammed eş-Şâzelî, Seyyid Ramazan Ahmed, Dâru'I-Maârif, Kahire trs.

İbn Sa'd, Muhammed b. Sa'd b. Meni' ez-Zührî (ö. 230/845), Kitâbu'ttabakâti'l-kebîr, I-XI, thk. Ali Muhammed Ömer, Mektebetü'l-Hancî, Kahire $1421 / 2001$.

Kirmânî, Muhammed b. Yûsuf b. Ali b. Saîd Şemsüddin (ö. 786/1384), el-Kevâkibu'd-derârî fî şerhi Sahîhi'l-Buhârî, I-XXV, Dâru Ihyâi't-Turâsi'l-Arabî, Beyrut 1401/1981.

Koçyiğit, Talat, Hadis Terimleri Sözlüğü, Rehber Yay., Ankara 1992. Hadîs Usûlü, Türkiye Diyanet Vakfı Yay., Ankara 2013.

Mizzî, Cemalüddin Ebu'I-Haccâc Yusuf (ö. 742/1342), Tehzîbu'l-Kemâl fi esmâi'r-ricâl, I-XXXV, thk. Beşşâr Avvâd Maruf, Müessesetü'r-Risâle, Beyrut $1403 / 1983$.

Tuhfetü'l-eşrâf bi-ma'rifeti'l-etrâf, I-XIII, thk. Abdüssamed Şerefüddin, el-Mektebetü'l-İslâmî/ed-Dâru'l-Kayyime, byy. 1403/1983.

Müslim, Ebü'l-Huseyn Müslim b. Haccâc (ö. 261/875), el-Câmiu'ssahîh, I-III, Çağrı Yay. ve Dâru Sehnûn, İstanbul 1413/1992. 
Nesâî, Ebû Abdurrahman Ahmed b. Şuayb b. Ali el-Horâsânî (ö. 303/915), Sünenü'n-Nesâî, tsh. Ahmed Şemsüddin, Dâru'l-Kütübi'l-İlmiyye, Beyrut 2009.

Sezgin, M. Fuad, Buhârînnin Kaynakları, Otto Yay., Ankara 2012.

Süyûtî, Celaleddin Abdurrahman (ö. 911/1505), Tedrîbü'r-râvî fî şerhi Takrîbi'n-Nevevî, Dâru İbn Hazm, Beyrut 1430/2009.

Tahhân, Mahmûd, Teysîru mustalahi'l-hadîs, Mektebetü'l-Maârif, Riyad 1432/2011.

Tahânevî, Muhammed Ali (ö. 1158/1745'ten sonra), Mevsûatü keşşâfi Istılâhâti'l-funûni ve'l-ulûm, I-II, thk. Ali Dehrûc, Mektebetü Lübnan Nâşirûn, Lübnan 1996.

Tirmizî, Ebû Îsâ Muhammed b. Îsâ b. Sevre (ö. 279/892), Câmiu'tTirmizî, Dâru's-Selâm, Riyad 1999.

Türkî, Muhammed b. Türkî, Temyîzü'l-mühmel mine’s-Süfyâneyni ve meahû vesâilü temyîzi'l-mühmeleyn, Dâru'l-Âsıme, Riyad 1431/2010.

Uğur, Mücteba, Ansiklopedik Hadis Terimleri Sözlüğü, TDV Yayınları, Ankara 1992.

Zehebî, Şemsüddin Muhammed b. Ahmed b. Osman (ö. 748/1374), Siyeru a'lâmi'n-nübelâ, I-XXIX, thk. Şuayb el-Arnaût, Ali Ebû Zeyd, Muhammed Nuaym el-Araksûsî, Müessesetü'r-Risâle, Beyrut 1402/1982. 


\section{The Term of "Muhmal" in the Science of Hadith and the Problem of Determination of Sufyan, One of the Narrators of Sahih al-Bukhari}

Citation / @)- Çelikan, S. (2018). The Term of "Muhmal" in the Science of Hadith and the Problem of Determination of Sufyan, One of the Narrators of Sahih al-Bukhari, Cukurova University Journal of Faculty of Divinity, 18 (2), 764-795.

Abstract- In the basic sources of hadith, in connection with mention of chain of transmission (isnād), it is one of the frequent disposition of the authors (musannif) not to point out the identity of some of the narrators (rāwi) obviously. Upon consideration of the high level of knowledge about isnāds and rāwis, even though this is common and understandable in the first periods like 2nd and 3rd century $\mathrm{AH}$, where the hadiths began to be classified, it raises the problem of the level of authenticity of isnād for the following periods when the information in this field is reduced. One of the examples of this application with different types is "Ihmal" or "muhmal". In this research, the meaning of this term is emphasized and to what extent especially the two important narrators in Bukharis (d. 256/870) sahih, Sufyan ath-Thawri (d. 161/778) and Sufyan ibn Uyaynah (d. 198/814) were used, and the possibility of impression from each other is tried to be determined on the basis of some important annotations of the work. Again, because of the disputes about the determination of Sufyan and the reasons for the different opinions, the biographies of these narrators and the states of justice and Zabt (Methods of preserving Hadith), and the value of such narrations in general in terms of authenticity, have also been examined because of their direct influence on the authenticity of chain of transmission.

Keywords- Sufyan ibn Uyaynah, Sufyan ath-Thawri, Ihmal, muhmal, isnād. 